\title{
An Agonist of the Protective Factor SIRT1 Improves Functional Recovery and Promotes Neuronal Survival by Attenuating Inflammation after Spinal Cord Injury
}

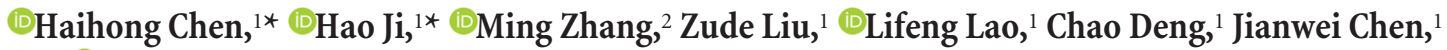 \\ and $\odot$ Guibin Zhong ${ }^{1}$ \\ Departments of ${ }^{1}$ Orthopedics and ${ }^{2}$ Transplantation, Shanghai Jiao Tong University School of Medicine, Renji Hospital, Shanghai 200127, People's Republic \\ of China
}

\begin{abstract}
Targeting posttraumatic inflammation is crucial for improving locomotor function. SIRT1 has been shown to play a critical role in disease processes such as hepatic inflammation, rheumatoid arthritis, and acute lung inflammation by regulating inflammation. However, the role of SIRT1 in spinal cord injury (SCI) is unknown. We hypothesized that SIRT1 plays an important role in improving locomotor function after SCI by regulating neuroinflammation. In this study, we investigate the effect of SIRT1 in SCI using pharmacological intervention (SRT1720) and the Mx1-Cre/loxP recombination system to knock out target genes. First, we found that SIRT1 expression at the injured lesion site of wild-type (WT) mice (C57BL/6) decreased $4 \mathrm{~h}$ after SCI and lasted for $3 \mathrm{~d}$. Moreover, administration of SRT1720, an agonist of SIRT1, to WT mice significantly improved functional recovery for up to $28 \mathrm{~d}$ after injury by reducing the levels of proinflammatory cytokines, the number of M1 macrophages, the number of macrophages/microglia, and the accumulation of perivascular macrophages. In contrast, administration of SRT1720 to SIRT1 knock-out (KO) mice did not improve locomotor recovery or attenuate inflammation. Furthermore, SIRT1 KO mice exhibited worse locomotor recovery, increased levels of inflammatory cytokines, and more M1 macrophages and perivascular macrophages than those of WT mice after SCI. Together, these findings indicate that SRT1720, an SIRT1 agonist, can improve functional recovery by attenuating inflammation after SCI. Therefore, SIRT1 is not only a protective factor but also an anti-inflammatory molecule that exerts beneficial effects on locomotor function after SCI.
\end{abstract}

Key words: inflammatory cytokines; macrophage/microglia; Mx1-cre; SIRT1; spinal cord injury; SRT1720

Significance Statement

Posttraumatic inflammation plays a central role in regulating the pathogenesis of spinal cord injury (SCI). Here, new data show that administration of SRT1720, an SIRT1 agonist, to wild-type (WT) mice significantly improved outcomes after SCI, most likely by reducing the levels of inflammatory cytokines, the number of macrophages/microglia, perivascular macrophages, and M1 macrophages. In contrast, SIRT1 KO mice exhibited worse locomotor recovery than that of WT mice due to aggravated inflammation. Taken together, the results of this study expand upon the previous understanding of the functions and mechanisms of SIRT1 in neuroinflammation following injury to the CNS, suggesting that SIRT1 plays a critical role in regulating neuroinflammation following CNS injury and may be a novel therapeutic target for post-SCI intervention.

\section{Introduction}

Traumatic spinal cord injury (SCI) results from primary damage to the spinal cord followed by secondary injury (Ambrozaitis et

\footnotetext{
Received Sept. 29, 2016; revised Jan. 23, 2017; accepted Jan. 31, 2017.

Author contributions: H.C., H.J., M.Z., Z.L., and G.Z. designed research; H.C., H.J., C.D., and G.Z. performed research; H.C., H.J., C.D., and G.Z. contributed unpublished reagents/analytic tools; H.C., H.J., L.L., and G.Z. analyzed data; H.C., H.J., J.C., and G.Z. wrote the paper.

This work was supported by the grants from the National Natural Science Foundation of Youth Program (№. 0801157).

*H.C. and H.J. contributed equally to this work.

The authors declare no competing financial interests.
}

al., 2005). The primary damage to the spinal cord directly destroys tissues and cannot be ameliorated. However, secondary damage caused by oxidative stress, free radical generation, edema, posttraumatic inflammatory reactions, and other processes is believed to lead to further tissue damage followed by permanent impairment of motor function, and this type of dam-

Correspondence should be addressed to Guibin Zhong, Department of Orthopedics, Shanghai Jiao Tong University School of Medicine, Renji Hospital, 1630 Dongfang Road, Shanghai 200127, People's Republic of China. E-mail: zhonggb@foxmail.com.

DOI:10.1523/JNEUROSCI.3046-16.2017

Copyright $@ 2017$ the authors $\quad 0270-6474 / 17 / 372916-15 \$ 15.00 / 0$ 
age can be reduced (Dumont et al., 2001; Hall and Springer, 2004; Profyris et al., 2004; Fehlings and Baptiste, 2005; Maier and Schwab, 2006). Posttraumatic inflammation, which includes inflammatory cell infiltration, microglia activation, and inflammatory cytokine production, is the major component of secondary injury and plays a central role in regulating the pathogenesis of acute and chronic SCIs (Bethea et al., 1998; Bethea, 2000; Conti et al., 2003; Beattie, 2004). Inflammatory cells promote secondary damage through the generation of reactive oxygen species and the release of proinflammatory cytokines. Uncontrolled immune responses may damage healthy tissue and aggravate secondary injury. Many studies have shown that regulation of posttraumatic inflammation is required to maximize functional recovery (Kwon et al., 2004; Rowland et al., 2008; Courtine et al., 2011; Donnelly et al., 2011; David et al., 2012a).

Macrophages play central roles in the innate immune response and exert distinct tissue repair activities after SCI (David and Kroner, 2011). Postinjury tissue repair involves regulation of the balance between two major populations of macrophages: proinflammatory type I (M1) and anti-inflammatory type II (M2) macrophages (Shechter et al., 2013). Whether macrophages aggravate secondary injury or promote wound repair predominantly depends on whether the cells are induced to differentiate into M1 or M2 macrophages (Cheng et al., 1996; Kuo et al., 2007, 2011; Shechter et al., 2013). M1 macrophages, which produce high levels of nitric oxide and proinflammatory cytokines, such as IL- $1 \beta$, IL- 6 , and TNF- $\alpha$, frequently induce cytotoxic processes and are correlated with the severity of disease progression in SCI (Busch et al., 2009). In contrast, M2 macrophages, which produce anti-inflammatory cytokines, such as IL-4, IL-10, and IL-13, exhibit anti-inflammatory activities, scavenge debris, promote angiogenesis, and are involved in tissue remodeling and repair (Kigerl et al., 2009). In addition, decreasing hematogenous macrophage accumulation at the site of SCI is neuroprotective and facilitates recovery (Popovich et al., 1999). Reducing the number of M1 macrophages and perivascular macrophages or inducing M2 macrophages following acute SCI has been reported to enhance tissue repair and improve locomotor recovery. (Gordon, 2003; Mantovani et al., 2004; Schwartz and Yoles, 2006; Kigerl et al., 2009; Cassetta et al., 2011; David and Kroner, 2011; Shechter et al., 2013).

SIRT1, a member of the Sirtuin family, is a highly conserved nicotinamide adenine dinucleotide-dependent class III protein deacetylase. SIRT1 has been shown to play a critical role in regulating various metabolic and pathophysiological processes, such as inflammation, apoptosis, stress resistance, differentiation, and aging (Bordone and Guarente, 2005; He et al., 2010; Busch et al., 2012; Lim et al., 2012; Xie et al., 2013; Shinozaki et al., 2014). In addition, SIRT1 is directly implicated in the modulation of inflammatory responses by deacetylation of histones and critical transcription factors, such as nuclear factor $\kappa \mathrm{B}$, resulting in the transcriptional repression of various genes related to inflammation (Yeung et al., 2004; Kauppinen et al., 2013). However, to our knowledge, the protective and anti-inflammatory effects of SIRT1 in SCI have not been studied. We hypothesize that SIRT1 plays a critical role in protecting against proinflammatory responses in SCI and may represent a potential novel therapeutic target for treating SCI.

\section{Materials and Methods}

Animals. The Cre/loxP recombination system was used to generate SIRT1 knock-out (KO) mice as described previously (Siegel et al., 2004). Mx1-Cre (JAK 003556) transgenic mice and SIRT1 floxed mice (JAK
Table 1. Real-time PCR primer sequences

\begin{tabular}{lll}
\hline Gene & Forward primer $\left(5^{\prime}-3^{\prime}\right)$ & Reverse primer $\left(5^{\prime}-3^{\prime}\right)$ \\
\hline INOS & CGCTTGGGTTTGTTCACT & TCTTTCAGGTCACTTTGGTA \\
CD86 & ATCAAGGACATGGGCTCGTA & GAAGTTGGCGATCACTGACA \\
Arginase1 & GCTTGCTTCGGAACTCAAC & CGCATTCACAGTCACTTA GG \\
CD206 & CAAAAACTGACTGGGCTTCC & GCCCTTGATTCCAAAGAGTG \\
CCR2 & GAGGTCTCGGTTGGGTTG TA & CACTGTCTTTGAGGCTTGTT \\
CXCL10 & TCTCCATCACTCCCCTTT AC & TTCGGCAGTTACTTTTGTT \\
IL-6 & CCAATGCTCTCCTAACAGAT & TGTCCACAAACTGATATGCT \\
TNF- $\alpha$ & GTACAAGGAGAACCAAGCAA & CCGTCTTTCATTACACAGGA \\
IL-1 $\beta$ & TTCAGGCAGGCAGTATCA & GTCACACACCAGCAGGTTAT \\
IL-10 & ACATACTGCTAACCGACTCC & CCACTGCCTTGCTCTTATT \\
GAPDH & TCAACAGCAACTCCCACTCTTCCA & ACCCTGTTGCTGTAGCCGTATTCA
\end{tabular}

008041) were obtained from The Jackson Laboratory. Four hundred micrograms of poly(deoxyinosinic/deoxycytidylic) acid (pI-pC; SigmaAldrich) were injected into the animals three times every $3 \mathrm{~d}$ to activate $\mathrm{Mx} 1-\mathrm{Cre}$ in vivo. $\mathrm{Mx1}$-Cre ${ }^{+} \mathrm{SIRT} 1{ }^{\text {loxP/loxP }}$ mice that had received three injections of $400 \mathrm{mg}$ of poly pI-pC were referred to as SIRT1 $\mathrm{KO}$ mice. Eight- to 10-week-old female mice (C57BL/6) weighing 20-25 g were used in the present study. All animal experiments were conducted according to the NIH Guide for the Care and Use of Laboratory Animals and the institutional guidelines of the Shanghai Jiaotong University School of Medicine.

Generation of the Mx1-Cre SIRT1 KO mice. The conditional targeted SIRT1 mutant mice (SIRT1co/co mice) carry an insertion mutation of the neomycin-resistant gene and loxp sequences in the SIRT1 gene flanking exon 4 that encodes a conserved Sir 2 motif. The mutation does not affect the expression of SIRT1 in SIRT1co/co mice. To convert the SIRT1 co allele into the SIRT1 KO allele, SIRT1co/co mice were crossed with Mx1-Cre transgenic mice to generate SIRT1 heterozygotes carrying the Mx1-Cre+ SIRT1+/loxp mice. The Cre recombinase is under the control of the Mx1 promoter. This promoter is silent in healthy mice, but can be induced to high levels of transcription by administration of interferon $\alpha$, interferon $\beta$, or synthetic double-stranded RNA (such as poly I:C). When combined with a mutant carrying a gene that has been flanked by loxP recognition sites, the expression of Cre recombinase causes the flanked gene to be removed. The breeding of Mx1-Cre+ SIRT1+/loxp male mice and Mx1-Cre+ SIRT1+/ loxp female mice resulted in Mx1-Cre+ SIRT1loxp/loxp (SIRT1 KO) mice. A PCR-based genotyping method was established to identify the wild-type and SIRT1 KO of the SIRT1 gene using two primers (forward primer, $5^{\prime}$ GGTTGACTTTAGGTCTTGTCTG-3'; reverse primer, 5' -CGTCCCTTG TAATGTTTCCC- $3^{\prime}$ ) and using Cre primers (forward primer, $5^{\prime}$-ACCTGAAGATGTTCGCGATTATCT-3'; reverse primer, $5^{\prime}$-ACCGTCAG TACGTGAGATATCTT- $3^{\prime}$ ) and the following thermocycler conditions: step $1,95^{\circ} \mathrm{C}, 10 \mathrm{~min}$; step $2,95^{\circ} \mathrm{C}, 15$ s; step $3,62^{\circ} \mathrm{C}, 60$ s; step 4 , repeat steps 2 and 3 a total of 40 times.

Surgical procedure. The mice were anesthetized with $1 \%$ pentobarbital. A clinically relevant moderate spinal cord contusion injury (60 kdyn force) was performed at the T10/T11 level using an Infinite Horizons Impactor (Precision Scientific) as described previously (Pomeshchik et al., 2014). This model was selected because it results in bilateral injury and paralysis and is also optimal for conclusive evaluation of the effects of therapeutic treatments. The bladder was manually expressed twice daily for $\sim 1$ week until the mice regained normal bladder function. Mice that underwent a laminectomy without impact served as sham controls. Animals that were contused in a nonsymmetrical manner were excluded from the experimental analyses.

SRT1720 treatment. SRT1720 (Selleck, catalog \#S1129), an SIRT1 agonist, was diluted in 3\% dimethyl sulfoxide (DMSO) in sterile PBS before intraperitoneal administration. The mice were randomly divided into the SRT1720 and vehicle groups. Immediately after SCI was induced, SRT1720 $(100 \mathrm{mg} / \mathrm{kg})$ or vehicle was injected intraperitoneally once daily for $7 \mathrm{~d}$. The control and sham mice were similarly injected with $3 \%$ DMSO in PBS.

Functional assessment. Hindlimb motor function recovery was assessed using the Basso Mouse Scale (BMS; Basso et al., 2006) by two raters 

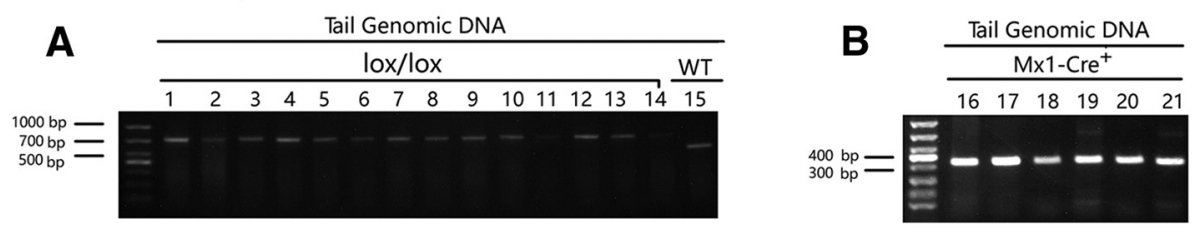

C
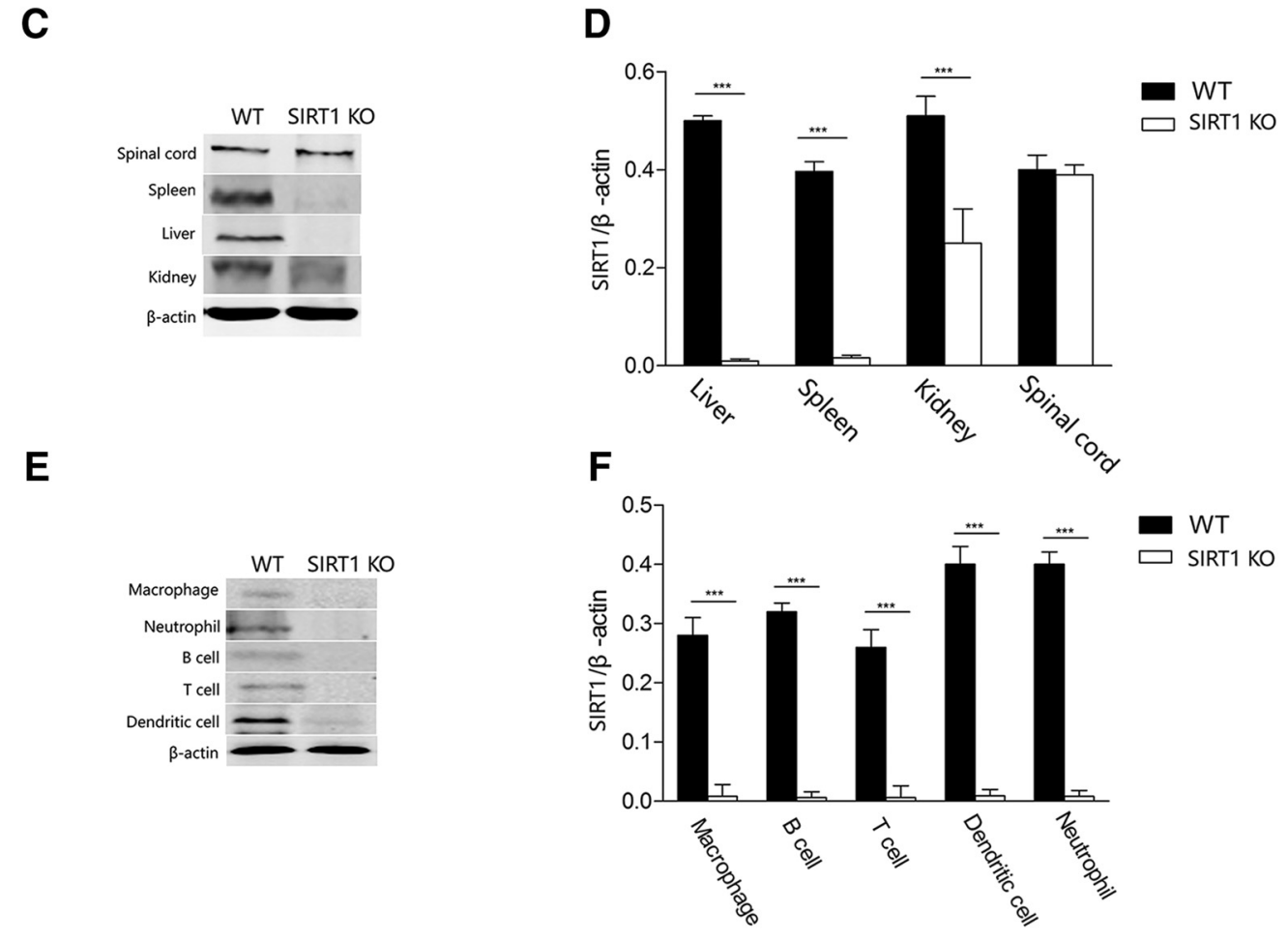

Figure 1. Confirmation of SIRT1 KO by PCR and SIRT1 protein expression in various tissues and inflammatory cells in SIRT1 K0 mice and WT mice. $A, B$, DNA samples from the tails of WT mice and SIRT1 K0 mice were used to show that the 750 bp 2-loxP allele-specific PCR product (lanes 1 to 14) and the 324 bp cre-specific PCR product (lanes 16 to 21) were detected only in Mx1-Cre ${ }^{+}$ SIRT1 ${ }^{\text {loxP/loxP }}$ mice (SIRT1 K0), while in WT mice, only the 550 bp PCR product was amplified (lane 15). C, D, Western blotting: SIRT1 expression in various tissues from SIRT1 K0 mice and WT mice. In SIRT1 K0 mice, SIRT1 protein exhibited significant reductions in the liver and spleen (both $>85 \%)$ and in the kidney $(\approx 48 \%)$, while there was minimal reduction in the spinal cords $(\sim 5 \%$, $p>$ 0.05 compared with WT). E, F, SIRT1 expression was identified in various inflammatory cells by WB. The SIRT1 K0 mice exhibited substantial reductions in the expression of SIRT1 protein in macrophages, neutrophils, DCs, and T and B cells (all $>85 \%, p<0.001$ compared with WT). ${ }^{* *} p<0.001$. The data are presented as the mean \pm SEM ( $n=4 /$ group).

who were blinded to the experimental groups. The BMS is a sensitive, valid, and reliable scale that assesses the degree of hindlimb functional recovery after SCI. The scale ranges from zero points (no ankle movement) to nine points (complete functional recovery) and includes assessment of ankle movement, plantar placement, weight support, stepping, coordination, paw position, and trunk stability. Locomotor activity was monitored by placing the mouse in an open field for 4 min and then recording the BMS scores for the right and left hindlimbs. Animals exhibiting a difference of more than points between the two hindlimbs were excluded from the experimental analysis. Motor function was assessed $24 \mathrm{~h}$ after injury, followed by weekly assessment for 4 weeks.

Tissue collection. After terminal anesthesia with $1 \%$ pentobarbital, the mice were transcardially perfused with heparinized (2500 IU/L) saline. The spleen, liver, kidney, and a $10 \mathrm{~mm}$ piece of spinal cord centered at the lesion epicenter were dissected, snap-frozen in liquid nitrogen and stored at $-80^{\circ} \mathrm{C}$ until further processing.

Quantitative real-time reverse transcription-PCR. TRIzol reagent (Invitrogen) was used to isolate RNA from the spinal cords and bone marrowderived macrophages (BMDMs) of the animals according to the manufacturer's instructions. Total RNA concentration and purity were determined from the 260/280 ratios of the optical density obtained from each sample (NanoDrop 1000, PeqLap). Complementary DNA was synthesized from $1 \mu \mathrm{g}$ of total RNA using a TaKaRa reverse transcription (RT) kit and random hexanucleotide primers (BioTNT). The expression levels of the target genes were measured in a mixture consisting of $0.5 \mu \mathrm{l}$ of the reversed- transcribed cDNAs, $2.5 \mu \mathrm{l}$ of RNase-free water (Invitrogen), $5 \mu \mathrm{l}$ of $2 \times$ SensiMix SYBR and fluorescein (Bioline), and $2 \mu \mathrm{l}$ of primers $(10 \mathrm{pmol} / \mu \mathrm{l})$. Quantitative real-time RT-PCR analysis was performed using the MyIQ detection system (Bio-Rad). Relative expression levels were calculated using the $\Delta \Delta C T$ method. The data are expressed as the target gene level relative to that of a reference gene (GAPDH). The values for the sham animals were set to $100 \%$. The data of interest are presented as relative expression. All realtime RT-PCR primer sequences are listed in Table 1.

Cell culture. BMDMs were extracted from the femurs and tibias of 8- to 10-week-old female C57BL/6 mice and SIRT1 KO mice as described previously (Gensel et al., 2009) and plated at a density of $1 \times 10^{6} \mathrm{cells} / \mathrm{ml}$ in differentiation medium (DMEM supplemented with $1 \%$ penicillin/ streptomycin, 10\% FBS, and 10\% of the supernatant from sL929 cells). The supernatant collected from L929 cells contains macrophage colonystimulating factor, which promotes differentiation of bone marrow cells into macrophages (Burgess et al., 1985). BMDMs were allowed to differentiate for $7 \mathrm{~d}$ in culture. On day 7 , the cells were replated in 12-well plates at a density of $1 \times 10^{6} \mathrm{cells} / \mathrm{ml}$ and cultured in differentiation medium without L929 supernatant. On day 8, the cells were stimulated to differentiate into M1 macrophages using lipopolysaccharide (LPS; 10 $\mathrm{ng} / \mathrm{ml}$; Sigma-Aldrich) plus IFN- $\gamma(10 \mathrm{ng} / \mathrm{ml}$; Sigma-Aldrich) or into M2 macrophages using IL-4 (10 ng/ml; Sigma-Aldrich). SRT1720 (1 ng/ml; Selleck) was added at the time of stimulation. Twenty-four hours after incubation, RNA was isolated from the stimulated macrophages, and the 
A

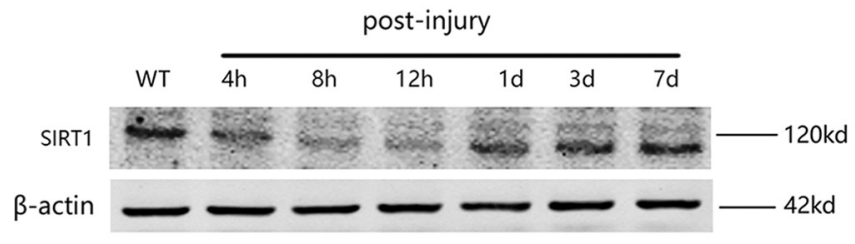

B

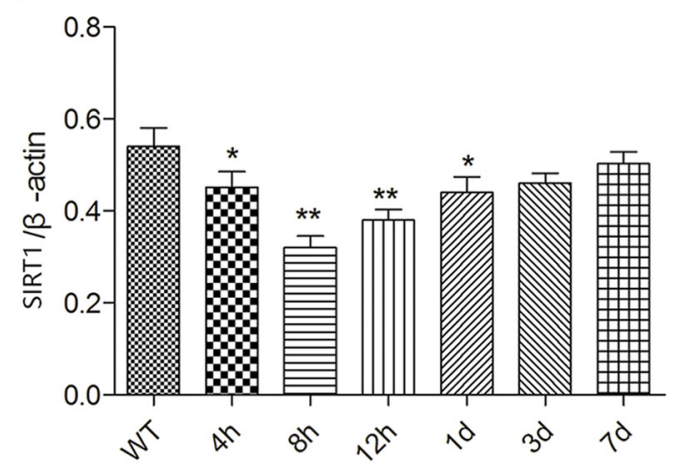

C

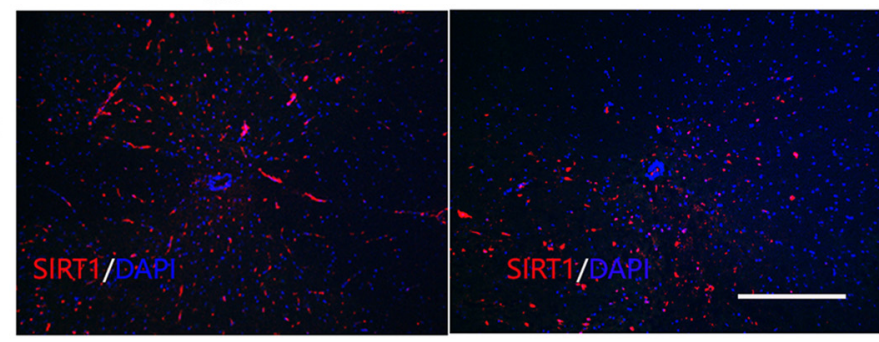

D

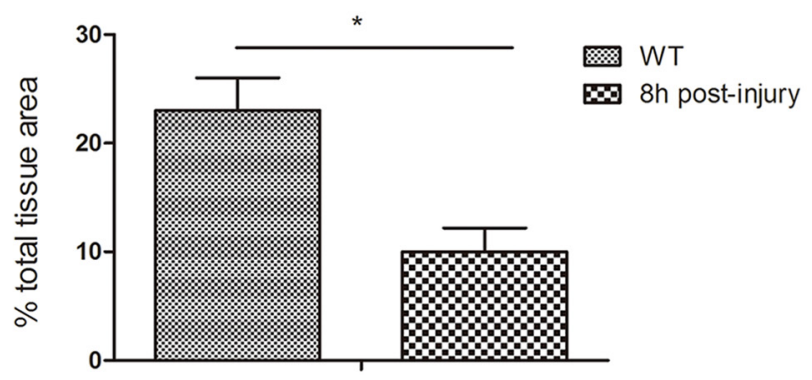

Figure 2. Decreased expression of SIRT1 protein in the injured spinal cords during the early stages of SCI. A, C, Western blotting. SIRT1 expression was decreased until $3 \mathrm{~d}$ after injury. $B, D$, Immunofluorescence: SIRT1 expression at the lesion epicenter $8 \mathrm{~h}$ after $S C l .{ }^{*} p<0.05 ;{ }^{* *} p<0.01$ (after injury vs WT). The data are presented as the mean \pm SEM ( $n=4 / \mathrm{group}$ ). Scale bar, $200 \mu \mathrm{m}$.

expression of cytokines, M1 markers, and M2 markers was examined using RT-PCR.

Western blotting analysis. The frozen spinal cord, spleen, liver, and kidney tissues and various inflammatory cells were homogenized in lysis buffer (15 mм HEPES, pH 7.9, 0.25 м sucrose, $60 \mathrm{~mm} \mathrm{KCl,} 10 \mathrm{~mm} \mathrm{NaCl}$, $1 \mathrm{~mm}$ ethylene glycol tetraacetic acid, $1 \mathrm{~mm}$ phenylmethylsulfonyl fluoride, and $2 \mathrm{~mm} \mathrm{NaF}$ ) to extract the proteins. The following antibodies were used for Western blotting (WB): acetylated NF- $\kappa$ B p65 (Cell Signaling Technology, RRID: AB_823580), NF- $\kappa$ B p65 (Cell Signaling Technology, RRID: AB_10859369), phospho-NF- $\kappa$ B p65 (Cell Signaling Technology, RRID: AB_331284), $\beta$-actin (Cell Signaling Technology, RRID: AB_2223172), iNOS (Cell Signaling Technology, RRID: AB_ 1078202), CD86 (Abcam, RRID: AB_869050), and SIRT1 (Cell Signaling Technology, RRID: AB_1196631). All antibodies were obtained from Cell Signaling Technology. The bands were visualized using an enhanced chemiluminescence substrate (Pierce). The MultiGauge image analysis program (version 3.0, Fujifilm) was used for band densitometry.

Detection of TNF- $\alpha, I L-1 \beta, I L-6$, and IL-10 in the spinal cord using ELISAs. Samples were collected at three time points and immediately homogenized in extraction buffer [20 mM Tris, pH 7.4 (Sigma-Aldrich) containing $150 \mathrm{~mm} \mathrm{NaCl}$ (Sigma-Aldrich), 1 mм EDTA (Sigma-Aldrich), 2 mм 2-N-morpholinoethanesulfonic acid (Sigma-Aldrich), and one complete protease inhibitor tablet (Roche)]. The cytokine levels in the mouse spinal cords were measured using ELISAs specific for TNF- $\alpha$, IL- $1 \beta$, IL- 6 , and IL-10 according to the manufacturer's instructions. The content in each sample was obtained from a total length of $10 \mathrm{~mm}$ centered around the injured area (Amin et al., 2014).

In vitro migration assay. BMDM migration assays were conducted in transwell migration assay chambers (BD Life Sciences) following the addition of CCL2 (Sigma-Aldrich) to the lower chamber. SRT1720 (1 $\mathrm{ng} / \mathrm{ml}$; Selleck) and $1 \%$ DMSO were added, and $24 \mathrm{~h}$ after stimulation, BMDM migration assays were conducted.

Histology. Following perfusion with $4 \%$ paraformaldehyde (PFA), the spinal cords were postfixed in $4 \%$ PFA at $4^{\circ} \mathrm{C}$ for $21 \mathrm{~h}$ followed by cryoprotection in $10 \%$ sucrose for $24 \mathrm{~h}$ and in $20 \%$ sucrose for an additional $24 \mathrm{~h}$. A $10 \mathrm{~mm}$ piece of the spinal cord centered at the lesion epicenter (or respective area in the sham-operated animals) was embedded in Tissue-Tek OCT Compound (Sakura Finetek), frozen on liquid-nitrogen-supercooled isopentane, and stored at $-80^{\circ} \mathrm{C}$, and serial, transverse $20 \mu \mathrm{m}$ cryostat sections were cut (Leica). All histological studies were performed in a blinded fashion. The frozen sections were processed for immunofluorescence staining with primary antibodies against ionized calcium-binding adapter SIRT1 (1:200; Cell Signaling Technology, RRID: AB_1196631), molecule 1 (Iba-1; 1:250; Abcam, catalog \#ab178847), NeuN (1:200; Merck Millipore, RRID: AB_2571567), TUNEL (1:250; Abcam, catalog \#ab66110), CD68 (1:200; Abcam; RRID: AB_869007), CD86 (1:200; Abcam, RRID:AB_869050); CD163 (1:200; Abcam, catalog \#ab182422), or CD3 (1:200; Cell Signaling Technology, RRID: AB_10706943). On the following day, the appropriate Alexa Fluor-conjugated secondary antibodies (all from Cell Signaling Technology) were applied, and after the sections were washed and air dried, they were mounted using Vectashield mounting media with DAPI (Vector Laboratories) or subsequently processed for double-staining with compatible antibodies. The spinal cord sections were photographed using a digital camera (Color View 12 or F-view; SoftImaging Systems) attached to an Olympus AX70 microscope, and the fluorescence intensities were quantified with ImagePro Plus (Media Cybernetics) or ImageJ (W. Rasband, National Institutes of Health, Bethesda, MD) software by a researcher who was blinded to the treatment groups.

Myeloperoxidase activity. Myeloperoxidase (MPO; Abcam, catalog \#ab155458) activity, an indicator of polymorphonuclear leukocyte (PMN) accumulation, was determined $24 \mathrm{~h}$ after SCI as described previously (Mullane et al., 1985). Spinal cord tissues were obtained at the specified times after SCI and weighed. Each piece was homogenized in a solution containing $0.5 \%(\mathrm{w} / \mathrm{v})$ hexadecyltrimethyl-ammonium bromide dissolved in $10 \mathrm{~mm}$ potassium phosphate buffer, $\mathrm{pH} 7$, and centrifuged for $30 \mathrm{~min}$ at $20,000 \times \mathrm{g}$ at $4^{\circ} \mathrm{C}$. An aliquot of the supernatant was subsequently allowed to react with a solution containing $1.6 \mathrm{~mm}$ tetramethylbenzidine and $0.1 \mathrm{~mm} \mathrm{H}_{2} \mathrm{O}_{2}$. The rate of change in the absorbance was spectrophotometrically measured at $650 \mathrm{~nm}$. MPO activity is defined as the quantity of enzyme that degraded $1 \mu \mathrm{mol}$ of peroxide per minute at $37^{\circ} \mathrm{C}$ and is expressed in international units per gram of wet tissue. 
Isolation of inflammatory cells in mice. For isolation of neutrophils, $\sim 0.6 \mathrm{ml}$ peripheral blood was collected from each mouse in tubes containing EDTA (1.8 mg of EDTA per milliliter of blood) and diluted with $0.6 \mathrm{ml}$ Roswell Park Memorial Institute 1640 medium (RPMI) (dilution 1:1). Then, $0.6 \mathrm{ml}$ density gradient solution was carefully and slowly added to the bottom of the tube without mixing the phases. The density gradient solution was incubated at room temperature. The blood should separate into four distinct phases from top to bottom: platelets and plasma, mononuclear cells (white ring), density gradient solution, and granulocytes and erythrocytes. The upper red-blood-cell-poor neutrophil layer (Hirz and Dumontet, 2016) was collected. To isolate macrophages, we injected $1 \mathrm{ml} 3.8 \%$ Brewer thioglycolate medium into the peritoneal cavity of each mouse. After $3 \mathrm{~d}$, the abdomen of each mouse was washed with $70 \%$ ethanol, and $5 \mathrm{ml}$ cold DPBS was injected into the peritoneal cavity using a $5 \mathrm{ml}$ syringe attached to a 20 gauge needle. The needle was removed, and the peritoneal fluid was dispensed into a $50 \mathrm{ml}$ conical centrifuge tube. The samples were centrifuged for $10 \mathrm{~min}$ at $400 \times g$ in a refrigerated centrifuge. The supernatant was discarded, and the cell pellet was resuspended in RPMI 1640. The cells were counted with a hemocytometer, and the cell density was adjusted to $1 \times 10^{6}$ cells $/ \mathrm{ml}$. The phenotypes of $\sim 1 \times 10^{6}$ cells from each mouse were characterized by flow cytometry using antibodies against F4/80 (BD Biosciences, catalog \#565853), a surface antigen expressed on macrophages (Layoun et al., 2015). Different dendritic cell (DC) subsets and lymphocytes reside in the spleen. For isolation of DCs and lymphocytes, fresh spleens were obtained from the mice, and clumps of spleen tissue were plunged into a $50 \mathrm{ml}$ centrifuge tube filled with ice-cold sterile HBSS. The spleens were each placed in a $35 \mathrm{~mm}$ Petri dish, and the organs were minced into pieces using scissors. One milliliter of $37^{\circ} \mathrm{C} 2 \times$ digestion medium was added to the cell suspension, and the suspension was incubated in a $37^{\circ} \mathrm{C}$ water bath to thoroughly dissociate the tissues. One spleen typically yielded up to $60-100 \times 10^{6}$ cells after digestion. The phenotypes of the isolated cells were characterized by flow cytometry using antibodies against CD3 (BD Biosciences, RRID: AB_2034003), B220 (BD Biosciences, RRID: AB_394620), and CD11c (BD Biosciences, RRID: AB_395060) surface antigens, which are expressed on $\mathrm{T}$ cells, $\mathrm{B}$ cells, and DCs, respectively (Tassone and Fidler, 2012; Tavernier et al., 2015).

Statistical analyses. All data are presented as the mean \pm SEM. Unpaired $t$ tests were used to compare the means between two treatment groups. One-way ANOVA followed by Tukey's post hoc test was used for multiple comparisons. Behavioral data were analyzed using repeated measures two-way ANOVA followed by Bonferroni's post hoc test. All statistical analyses were performed in GraphPad Prism software for Windows, version 5.03 .

\section{Results}

Specificity and induction efficacy of the Mx1-Cre SIRT1 KO in vivo and in vitro

According to previous studies, the use of Mxl-Cre transgenic mice has been limited to mediating gene inactivation in the liver
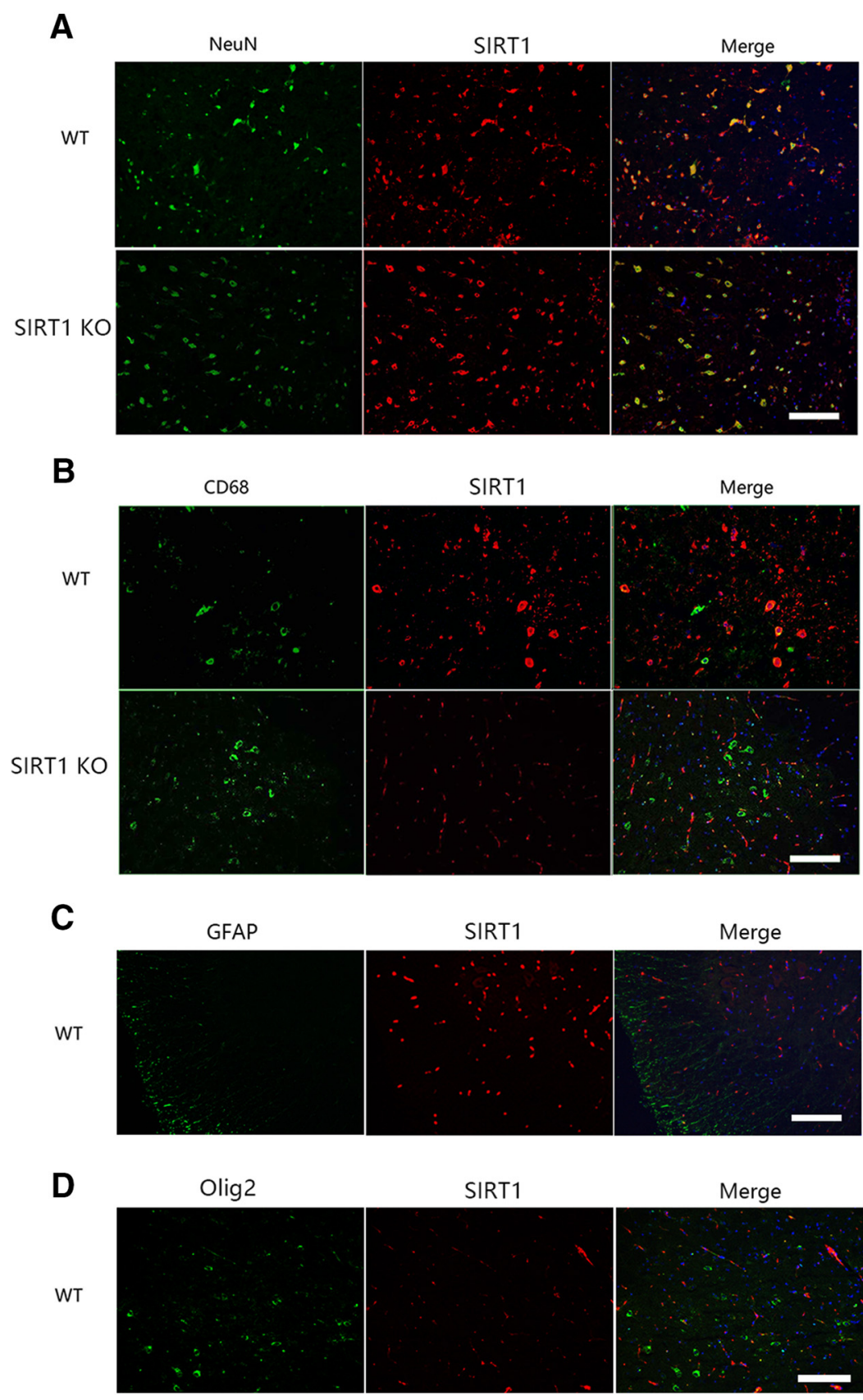

Figure 3. Expression of SIRT1 protein in mouse neurons, macrophages/microglia, oligodendrocytes, and astrocytes after SCI. microglia (CD68+) of WT and SIRT1 K0 mice $3 \mathrm{~d}$ after SCI $(p<0.0001, n=3)$. C, D, SIRT1 expression in oligodendrocytes and astrocytes of injured spinal cords from WT $3 \mathrm{~d}$ after SCI. Scale bars: $100 \mu \mathrm{m}$.

and immune system where recombination efficiency is high and the extent of Mx1-Cre-induced targeted gene deletion is less in CNS (Kühn et al., 1995; Lam et al., 1997; Lam and Rajewsky 1998; Rohlmann et al., 1998; Radtke et al., 1999; Alonzi et al., 2001). Therefore, we used Mx1-Cre-mediated SIRT1 KO mice to investigate the beneficial effects of targeting SIRT1 in injured spinal cords, with particular emphasis on targeting the immunomodulatory function of SIRT1. To demonstrate whether the LoxPflanked exon 2 of SIRT1 gene can be efficiently deleted in vivo, a Mx1-cre inducible transgenic line and Poly I:C system were used to delete the SIRT1 gene as described in Materials and Methods. The deletion of SIRT1 in Mx1-Cre-mediated SIRT1 KO mice was 

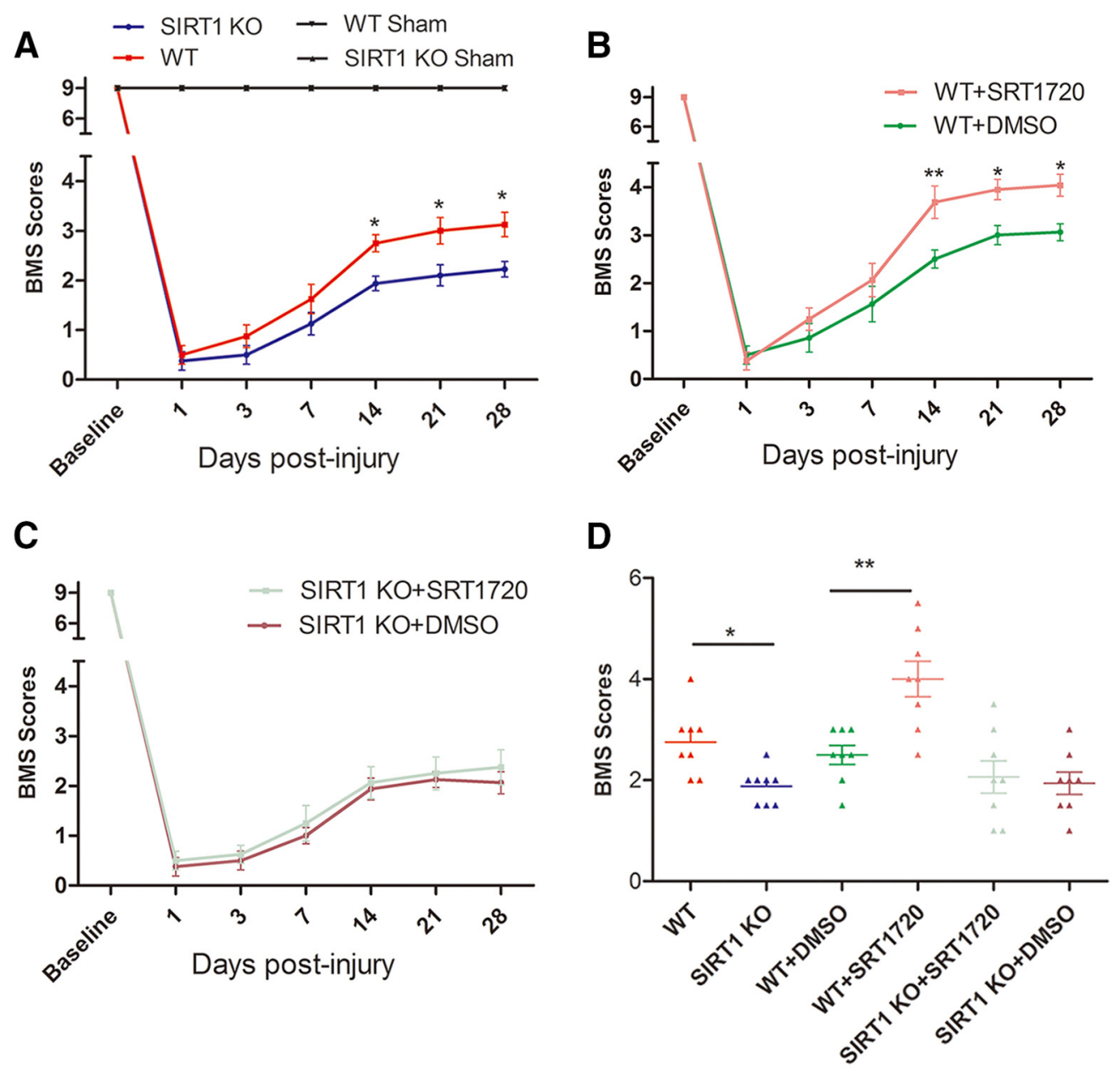

Figure 4. Administration of the SIRT1 agonist SRT1720 improved locomotor recovery in WT mice after SCI, whereas SIRT1 K0 mice exhibited worse motor function than WT mice after SCI ( $n=8 /$ group). $\boldsymbol{A}-\boldsymbol{C}$, Functional recovery was assessed in eight groups on days $1,3,7,14,21$, and 28 after injury. Compared with WT mice, the SIRT1 KO mice exhibited worse BMS scores. The locomotor function of the WT mice in the SRT1720-treated group was significantly improved compared to that of the WT mice in the DMSO-treated group. There were no time course differences between the BMS scores of the SRT1720-treated SIRT1 K0 mice and the DMSO-treated SIRT1 KO mice. D, The dot plot indicates the BMS scores assigned to the individual mice from each mouse line at $14 \mathrm{~d}$ after $\mathrm{SCl} .{ }^{*} p<0.05 ;{ }^{* *} p<0.01$ (repeated measures two-way ANOVA).

confirmed by PCR analysis. The 750 bp 2-loxP allele-specific PCR product and the $324 \mathrm{bp}$ cre-specific PCR product were observed in SIRT1 KO mice. However, only the 550 bp PCR product was amplified in WT mice (Fig. 1A). To confirm that the deletion of SIRT1 exon2 results in deficiency of SIRT1 expression, we examined the expression of SIRT1 in the spinal cords and other tissues and in inflammatory cells of SIRT1 KO mice. The current study used WB to assess the reduction in SIRT1 expression in the SIRT1 KO mice compared with that in WT mice. The SIRT1 KO mice exhibited substantial reductions in SIRT1 protein expression in macrophages, neutrophils, DCs, and T and B cells in the liver and spleen (all $>85 \%, p<0.001$ compared with WT). However, there was minimal reduction in the SIRT1 protein expression in the spinal cords of the SIRT1 KO group $(\sim 5 \%, p>0.05$ compared with WT; Fig. $1 B, C$ ). These findings are consistent with those of a previous study (Kühn et al., 1995). Based on these results, the Mx1-Cre-mediated SIRT1 KO mice may be used to further investigate the role of SIRT1 in inflammatory cells following SCI. Thus, we hypothesized that SIRT1 KO mice would exhibit worse motor function than that of WT mice primarily due to the effect of targeting SIRT1 in inflammatory cells.

\section{SIRT1 expression in mice after SCI}

The role and expression of SIRT1 in SCI have not been studied. To elucidate the mechanism of SIRT1 in SCI, we used WB and immunofluorescence to examine the expression of SIRT1 protein in the spinal cords of mice after SCI. WB was performed on spinal cord protein extracts from WT and injured WT mice at various time points after injury. Our data showed that SIRT1 began to decline $4 \mathrm{~h}$ after SCI, and the minimum levels were observed at $8 \mathrm{~h}$ postinjury (hpi). SIRT1 expression returned to the WT level by the third day (Fig. $2 A, B$ ). Decreased SIRT1 expression was observed $8 \mathrm{~h}$ after SCI using immunofluorescence, and this result was consistent with the WB data (Fig. 2C,D).

\section{SIRT1 expression in specific cell types of injured spinal cords from WT mice and SIRT1 KO mice $3 \mathrm{~d}$ after SCI}

Next, we used double-labeling immunofluorescence to monitor SIRT1 expression in neurons and macrophages/microglia in the spinal cord at $3 \mathrm{~d}$ after SCI. NeuN and CD68 are immunological markers for neurons and macrophages/microglia, respectively. Approximately 97 and $93 \%$ of neurons ( $\mathrm{NeuN}+$ ) in the WT and SIRT1 KO mice, respectively, expressed SIRT1 $3 \mathrm{~d}$ after SCI ( $p>$ 0.05 ; Fig. $3 A$ ). Moreover, $71.2 \%$ of the macrophages/microglia in 
A

TNF-a

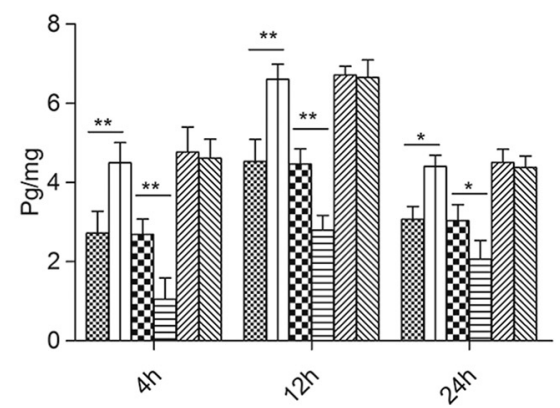

C

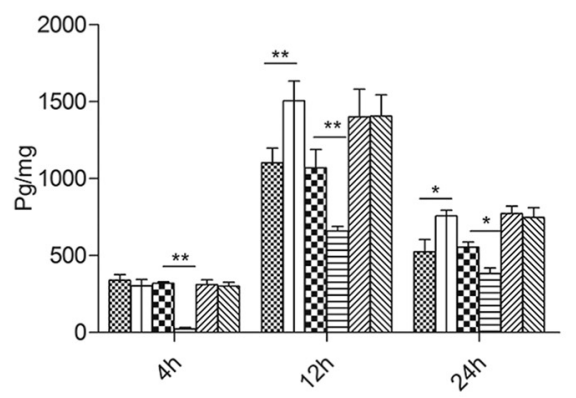

B

IL-10

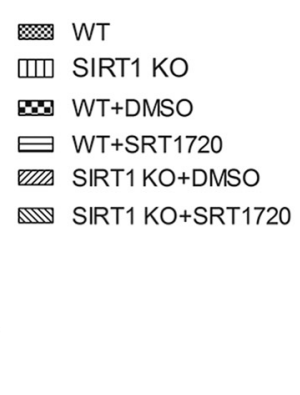

网 WT

m $\mathrm{m}$ SIRT1KO

$10.6 T+D M S O$

曰WT+SRT1720

IIRT SIRO+DMSO

SIRT1KO+SRT1720

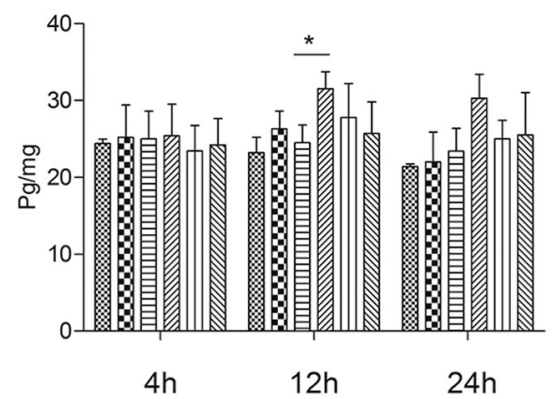

D

$\mathrm{IL}-1 \beta$

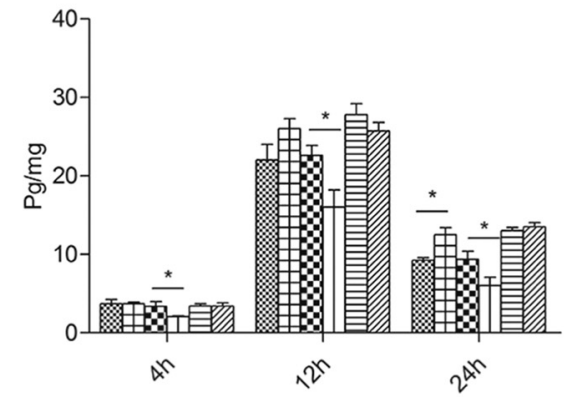

œT

8 SIRT1 KO

ÐWT+DMSO

WTI+SRT1720

سl SIRT1 KO+DMSO

SIRT1 KO+SRT1720

Figure 5. Administration of an SIRT1 agonist, SRT1720, decreased proinflammatory cytokine expression in WT mice during the early stages after injury, while SIRT1 K0 mice showed an increase in proinflammatory cytokine expression compared with WT mice. $\boldsymbol{A}-\boldsymbol{D}$, The time course of TNF- $\alpha, \mathrm{IL}-10, \mathrm{IL}-6$, and IL-1 $\beta$ protein expressions at 4,12 , and 24 hpi was analyzed by ELISA. ${ }^{*} p<0.05$; ${ }^{* *} p<0.01$. The data are presented as the mean \pm SEM $(n=4-6 /$ group $)$.

the WT mice expressed SIRT1. However, only $3 \%$ of the macrophages/microglia in the SIRT1 KO mice expressed SIRT1 $(p<$ 0.0001; Fig. 3B). In WT mice, no SIRT1 expression was found in astrocytes and oligodendrocytes of injured spinal cords after SCI (Fig. $3 C, D$ ).

\section{Locomotor recovery after SCI}

To study the effect of SIRT1 on the recovery of motor function after SCI, we divided the experimental mice into eight groups: wild-type sham, SIRT1 KO sham, WT (SCI), SIRT1 KO (SCI), WT+SRT1720 (SCI), WT+DMSO (SCI), SIRT1 KO+SRT1720 (SCI), and SIRT1 KO+DMSO (SCI) ( $n=8$ /group). We used the BMS to assess hindlimb locomotor motor function after SCI. In the SCI mice, locomotor function was abolished immediately after the contusion-induced SCI and was then assessed for $28 \mathrm{~d}$ following injury. We found that on days 14,21 , and 28 , the average BMS scores of the various groups exhibited significant differences, as follows: WT versus SIRT1 KO, $2.75 \pm 0.17$ versus $1.94 \pm$ $0.15,3.000 \pm 0.27$ versus $2.10 \pm 0.21$, and $3.125 \pm 0.25$ versus $2.23 \pm 0.16$, respectively; WT+DMSO versus $\mathrm{WT}+\mathrm{SRT} 1720$, $2.5 \pm 0.19$ versus $3.7 \pm 0.34,3.0 \pm 0.20$ versus $3.95 \pm 0.21$, and $3.06 \pm 0.18$ versus $4.04 \pm 0.23$, respectively (mean \pm SEM; Fig. $4 A, B)$. However, there were no significant differences between the DMSO-treated SIRT1 KO mice and the SRT1720-treated SIRT1 KO mice (Fig. 4C). The mean BMS locomotor scores of the individual mice were assessed on day 14 after SCI (Fig. 4D). Based on these results, SIRT1 promotes locomotor recovery after SCI, and the administration of $100 \mathrm{mg} / \mathrm{kg}$ SRT1720 improves motor behavior after SCI.
Time course of inflammatory cytokine expression after SCI To evaluate the effects of SIRT1 targeting on the expression of cytokines in the contused spinal cord during the early stage of SCI, we assessed the protein levels of four cytokines in injured spinal cords harvested 4,12 , and $24 \mathrm{~h}$ after SCI. At $4 \mathrm{hpi}$, the levels of three cytokines (TNF- $\alpha$, IL-6, and IL-1 $\beta$ ) were significantly reduced in the SRT1720-treated WT mice compared with those of the DMSO-treated WT mice. However, TNF- $\alpha$ levels were increased in the SIRT1 KO mice compared with those of the WT mice. At 12 hpi, the levels of these three cytokines (TNF- $\alpha$, IL-6, and IL-1 $\beta$ ) were significantly decreased in the SRT1720-treated mice, whereas IL-10 levels were increased compared with those of the DMSO-treated WT mice. In the SIRT1 KO mice, TNF- $\alpha$ and IL-6 levels were increased compared with those in the WT mice. At $24 \mathrm{hpi}$, the levels of three cytokines (TNF- $\alpha$, IL-6, and IL-1 $\beta$ ) remained decreased in the SRT1720-treated WT mice compared with those of the DMSO-treated WT animals. In the SIRT1 KO mice, TNF- $\alpha$, IL- 6 , and IL- $1 \beta$ levels were increased compared with those of the WT mice. However, there were no differences in the levels of the four cytokines between the SRT1720-treated SIRT1 KO mice and the DMSO-treated SIRT1 KO mice at any of the investigated time points (Fig. 5). Together, these data demonstrate that targeting SIRT1 regulates the expression of inflammatory cytokines during the early stage of SCI.

\section{Inflammatory cells in the injured spinal cord}

Leukocytes (neutrophils, macrophages, and T cells) assemble in the epicenter of injured spinal cords, where they not only participate in inflammatory SCI-induced events but are also involved 

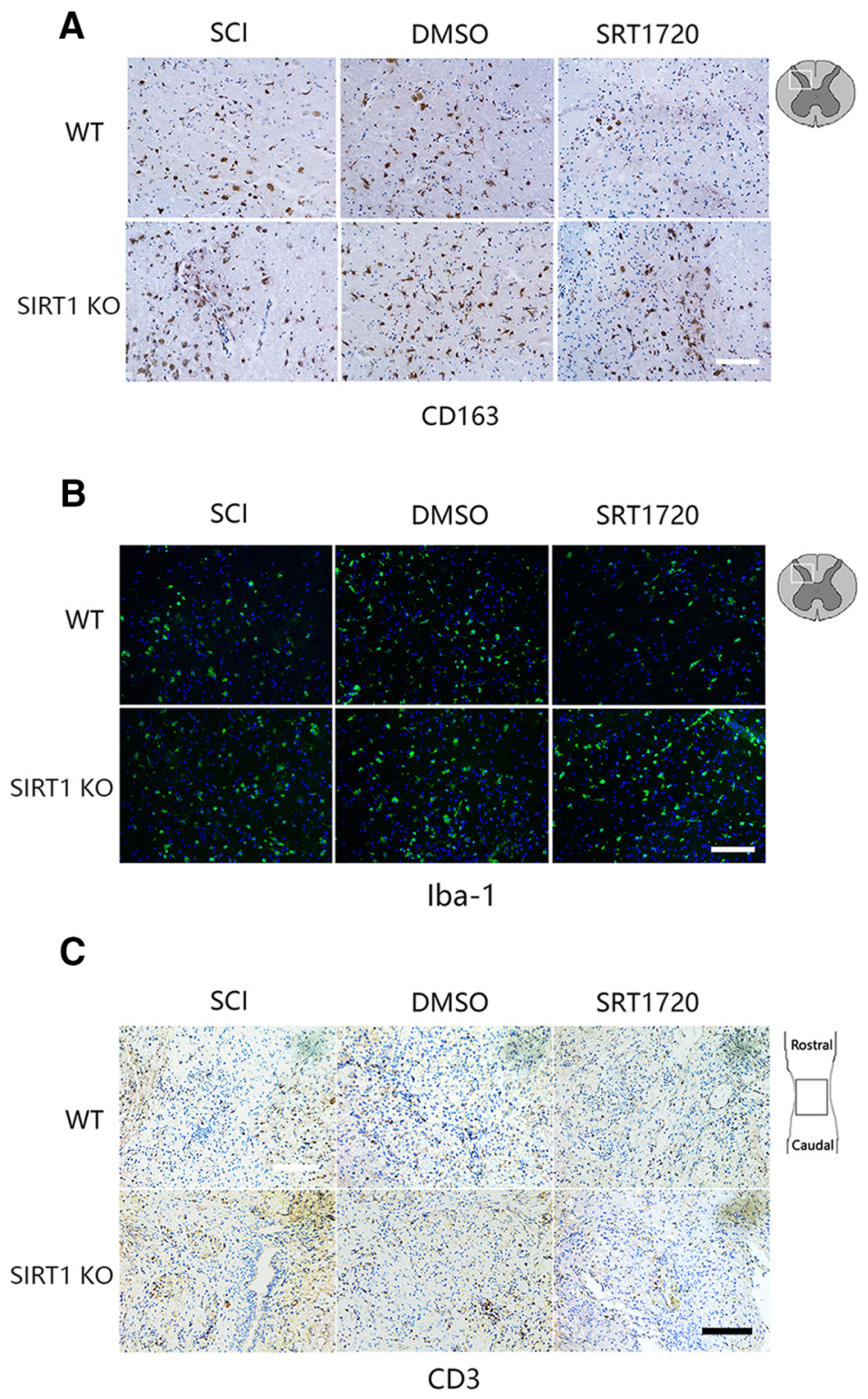

Figure 6. Fewer peripheral blood macrophages and macrophages/microglia were detected after the administration of the SIRT1 agonist SRT1720 to WT mice at $14 \mathrm{~d}$ after injury. There was a significant difference in the number of macrophages/microglia between SIRT1 K0 mice and WT mice. $\boldsymbol{A}, \boldsymbol{D}$, Macrophage infiltration. Spinal cord tissues were analyzed via immunohistochemistry using an anti-CD163 antibody (perivascular macrophages). More perivascular macrophages were detected in K0 mice compared with WT mice, while they were reduced in SRT1720-treated mice compared with DMSO-treated mice at the lesion epicenter $14 \mathrm{~d}$ after SCI. $\boldsymbol{B}, \boldsymbol{E}$, Macrophages/microglia in spinal cord tissues were analyzed via immunofluorescence using an anti-Iba- 1 antibody. A significant reduction in the number of macrophages/microglia and perivascular macrophages was observed in the WT mice following SRT1720 treatment; a substantially greater increase in the number of perivascular macrophages was observed in the SIRT1 KO mice compared with that in the WT mice at the lesion epicenter $14 \mathrm{~d}$ after SCI. $\boldsymbol{C}, \boldsymbol{F}$, The number of infiltrated CD3+ T cells at the lesion epicenter was analyzed at $14 \mathrm{~d}$ after injury using immunohistochemistry and was not significantly different in any of the groups. $\mathbf{G}, \mathrm{MPO}$ staining and activity were not significantly different in any of the groups. ${ }^{*} p<0.05 ;{ }^{* *} p<0.01$. The bars represent the mean \pm SEM ( $n=4 /$ group). Scale bars: $100 \mu \mathrm{m}$.

in limiting and repairing pathological damage, thereby imparting an anti-inflammatory effect (Fleming et al., 2006; Zhang and Gensel, 2014). To further explore the effects of targeting SIRT1 on macrophage, neutrophil, and $\mathrm{T}$ cell infiltration into injured spinal cord tissue after SCI, we used immunohistochemistry and immunofluorescence to analyze the inflammatory cells in the injured spinal cord tissue. CD163 is a marker for perivascular macrophages (Borda et al., 2008; Hawkes and McLaurin, 2009), and Iba-1 is a marker for macrophage/microglia (Hawkes and McLaurin, 2009). To identify the mechanism underlying functional outcomes, we assessed the numbers of macrophages $/ \mathrm{mi}$ croglia, perivascular macrophages, and lymphocytes in all eight groups at $14 \mathrm{~d}$ after injury. The results indicated that the number of perivascular macrophages was significantly increased in the SIRT1 KO mice compared with WT mice. In contrast, the number of perivascular macrophages in the WT mice was significantly decreased following SRT1720 administration. However, no significant effect was observed in the SIRT1 KO mice following SRT1720 administration. A significant decrease in the number of macrophages/microglia was observed in SRT1720-treated WT mice compared with that in the DMSO-treated WT mice (Fig. $6 A, B, D-F)$. The levels of CD3, a marker for T cells, were examined $14 \mathrm{~d}$ after injury, and the levels of MPO activity, as an indicator of PMN accumulation, were determined $24 \mathrm{~h}$ after SCI, as described previously (Mullane et al., 1985). However, there was no significant difference among the six groups in the number of 
A
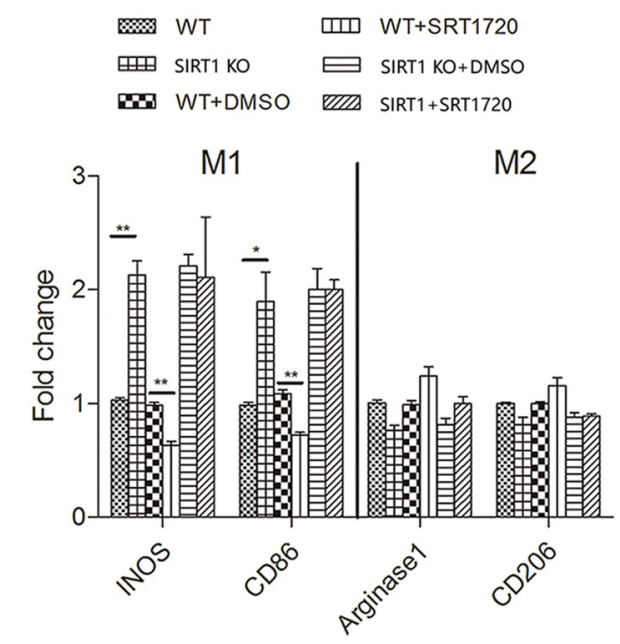

C
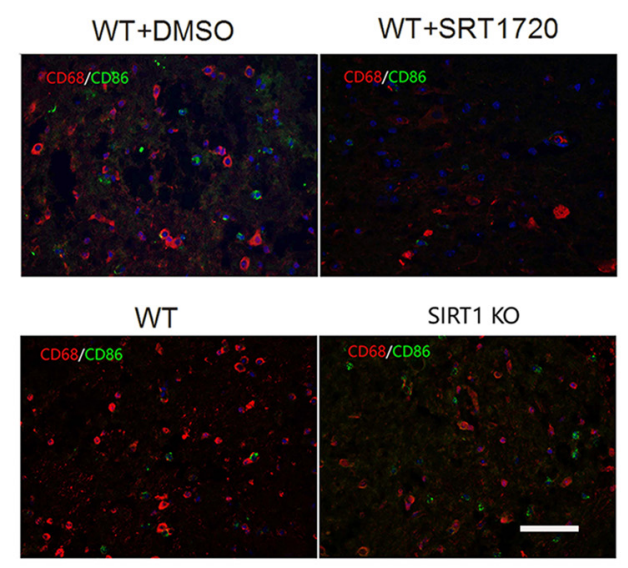

B
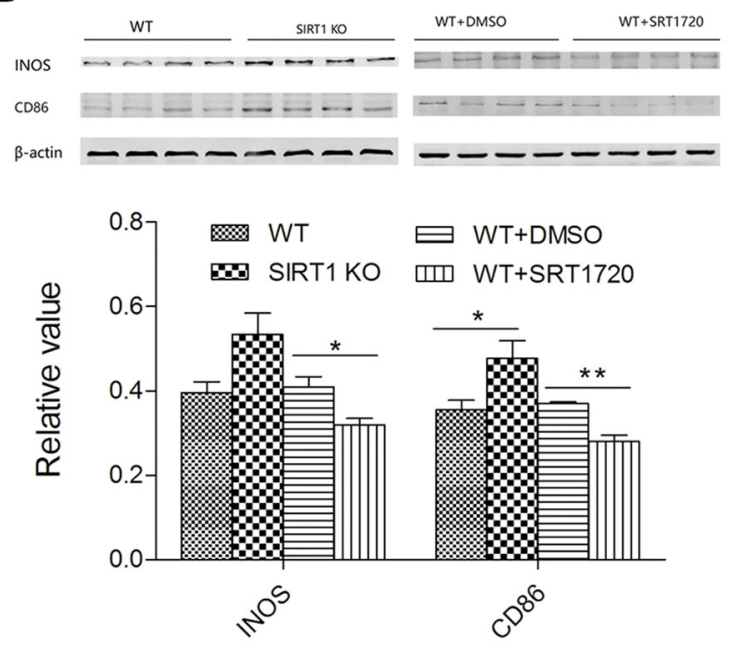

D

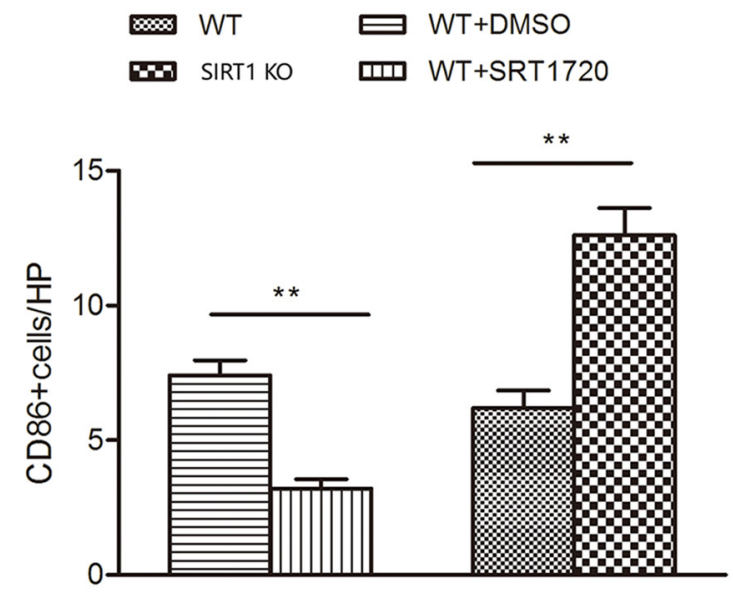

Figure 7. The administration of the SIRT1 agonist SR1720 to WT mice reduced the population of M1 macrophages in the injured spinal cord, while SIRT1 K0 mice showed an increase in M1 macrophages after injury compared to WT mice. $\boldsymbol{A}, \mathrm{RT}$-PCR of M1 markers (iNOS and (D86) and M2 markers (Arginase1 and (D206) at $14 \mathrm{~d}$ after injury. $\boldsymbol{B}$, WB was performed to further assess the M1 markers iNOS and CD86 at $14 \mathrm{~d}$ after SCI. Administration of SRT1720 induced a reduction in the expression of the M1 markers iNOS ( $p=0.054)$ and CD86 ( $p=0.041)$. SIRT1 K0 mice showed increased expression of the M1 markers iNOS ( $p=0.019)$ and CD86 ( $p=0.0011)$ compared with WT mice. $C, D$, Double-labeling immunofluorescence showing CD86-potitive macrophages (M1) $14 \mathrm{~d}$ after SCl. ${ }^{*} p<0.05 ;{ }^{* *} p<0.01$. The data are presented as the mean \pm SEM ( $n=4 /$ group). Scale bar, $50 \mu \mathrm{m}$.

infiltrated neutrophils and $\mathrm{CD} 3+\mathrm{T}$ cells (Fig. 6C,F,G). These findings suggest that activating SIRT1 may decrease the number of macrophages/microglia and the accumulation of perivascular macrophages after SCI, which has been reported to inhibit axon extension and induce neurotoxicity, while SIRT1 KO promotes the accumulation of perivascular macrophages after injury.

\section{Macrophage polarization in the injured spinal cord}

Furthermore, we investigated the effect of targeting SIRT1 on macrophage polarization after SCI via RT-PCR, WB, and doublelabeling immunofluorescence. Macrophages were divided into M1 and M2 populations. M1 markers included iNOS and CD86, and M2 markers included Arginase1 and CD206. As shown in Figure 7, $A$ and $B$, the RT-PCR and WB data collected $14 \mathrm{~d}$ after injury indicated that the expression of the M1 markers iNOS and CD86 was significantly decreased in the SRT1720-treated group of WT mice compared with that in the DMSO-treated group of WT mice, whereas the expression of M2 markers did not exhibit a significant difference. In contrast, the SIRT1 KO mice exhibited an increase in the M1 markers iNOS and CD86 compared with those of the WT mice. However, there was no significant difference in the macrophage populations in the SRT1720-treated SIRT1 KO mice and the DMSO-treated SIRT1 KO mice. The quantification of M1 macrophages (CD86+) in the injured spinal cord as revealed by double-labeling immunofluorescence was consistent with WB at $14 \mathrm{~d}$ after SCI (Fig. 7C,D). These results suggest that activating SIRT1 reduces the number of M1 macrophages in the injured spinal cord, while SIRT1 KO leads to the opposite result.

Apoptosis and neuronal survival in mice with SCI

As the augmentation of detrimental inflammation ultimately activates inflammatory mediators and affects neuronal survival, cell apoptosis, and functional behavior (David et al., 2012b), we analyzed the number of apoptotic cells in all groups after SCI using TUNEL staining. Apoptosis was quantified at $14 \mathrm{~d}$ after injury ( $n=4$ /group). Compared with the WT group, a significant increase in the number of TUNEL-positive cells was observed in the SIRT1 KO group $14 \mathrm{~d}$ after SCI. Administration of SRT1720 to the WT mice significantly decreased the number of apoptotic 
A

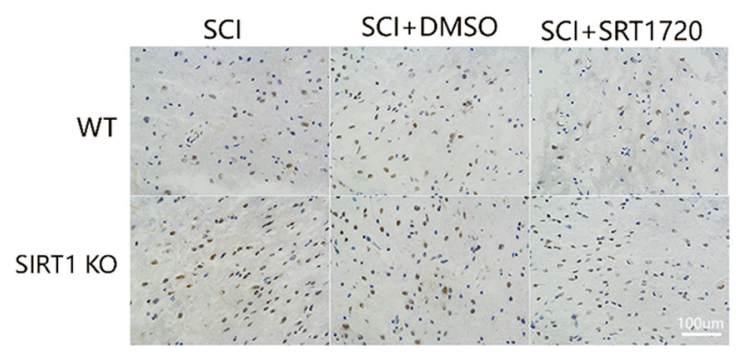

C

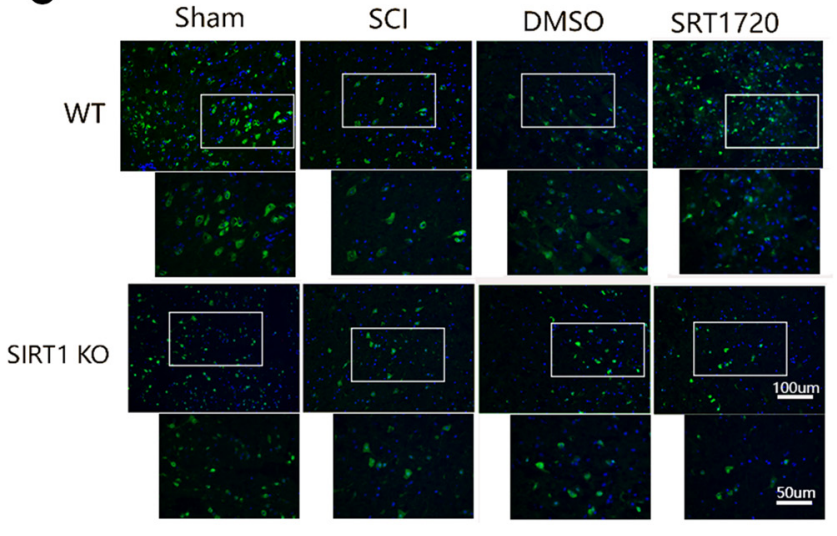

\section{B}

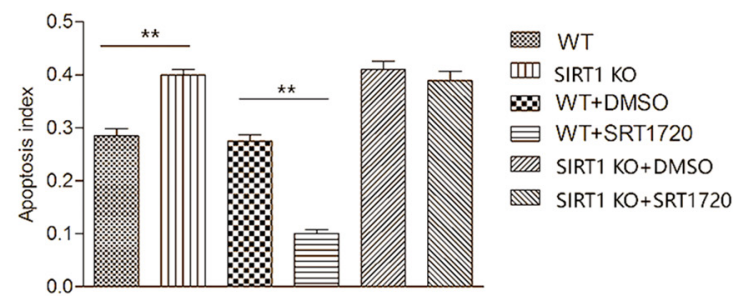

D

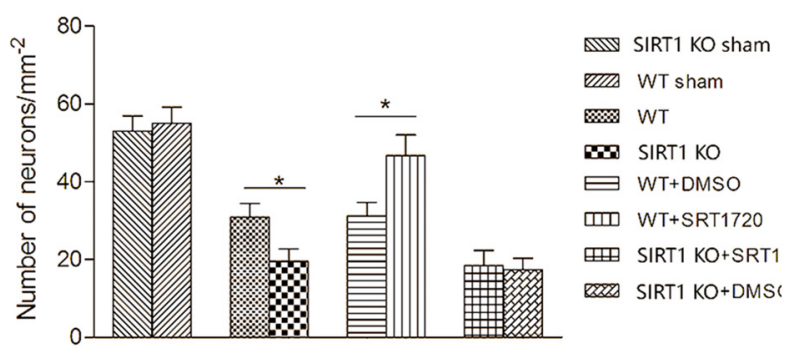

Figure 8. More apoptotic cells and worse neuronal survival were detected in the SIRT1 KO mice after injury; less apoptosis and better neuronal survival were observed after administration of an SIRT1 agonist (SRT1720) compared to those of the WT mice ( $n=4 /$ group). $\boldsymbol{A}, \boldsymbol{B}$, The number of apoptotic nuclei in the six groups was assessed using immunohistochemistry at $14 \mathrm{~d}$ after $\mathrm{SCl}$. TUNEL staining was used to evaluate apoptosis in all groups. Representative microscopic images of spinal cord sections obtained $14 \mathrm{~d}$ after $\mathbf{S C l}$ are shown. $\boldsymbol{C}, \boldsymbol{D}$, NeuN-positive cells at the lesion epicenter represent the neurons observed in the eight groups $28 \mathrm{~d}$ after SCl. The data are presented as the mean $\pm \mathrm{SEM} .{ }^{*} p<0.05$; ${ }^{* *} p<0.01$.

cells compared with that of the DMSO-treated group (Fig. $8 A, B$ ). In addition, the SRT1720-treated WT mice exhibited a significant increase in the number of neurons at the lesion epicenter at $28 \mathrm{~d}$ after SCI compared with that of the DMSO-treated WT mice as measured via NeuN immunoreactivity. However, the SIRT1 KO mice exhibited a significant decrease in the number of neurons at the lesion epicenter compared with that of the WT mice at $28 \mathrm{~d}$ after SCI (Fig. 8C,D).

\section{SIRT1 and NF- $\kappa$ B expression in SRT1720-treated mice at $24 \mathrm{~h}$ after SCI \\ To reveal the mechanism of SIRT1 regulation of inflammatory cytokines after SCI, we used WB to detect the expression of SIRT1 and its downstream target $24 \mathrm{~h}$ after SCI. Our results showed that SRT1720 administration induced a significant increase in the ex- pression of SIRT1 and a decrease in its downstream target acetyl- $\mathrm{NF}-\kappa \mathrm{B}$ p65. However, there was no difference in the total NF- $\kappa \mathrm{B}$ levels and phospho-NF- $\kappa$ B p65 levels in SRT1720-treated WT mice and DMSO-treated WT mice (Fig. 9A,B).}

\section{SIRT1 regulates macrophage polarization, migration and} inflammatory gene expression

As reported previously, macrophages, which accumulate at the injury site, are primarily derived from bone marrow (Wang et al., 2015). Therefore, to study the effects of SIRT1 on macrophages, we isolated and cultured mouse BMDMs. Cells were cultured in media with $10 \%$ of the supernatant from sL929 cells for $7 \mathrm{~d}$. Next, we directly analyzed the effects of genetic inhibition or chemical activation of SIRT1 on macrophage migration and polarization using an in vitro chemotaxis assay and RT-PCR to examine the mechanisms underlying the increased macrophage infiltration, changes in macrophage polarization, and increased inflammation in the spinal cord after SCI. When CCL2 was used as a chemoattractant, BMDMs from the SIRT1 KO mice exhibited increased migration compared with that of BMDMs from WT mice. However, when BMDMs from the WT mice were treated with SRT1720, an SIRT1 activator, CCL2-mediated macrophage migration was suppressed (Fig. 10A,B). Furthermore, the expression of M1 markers, M2 markers, chemotaxis receptors, and chemokine and inflammatory genes was analyzed using RT-PCR. As shown in Figure 10, the relative expression levels of the chemokine genes CCR2 and CXCL10; the proinflammatory genes TNF- $\alpha$, IL-6, and IL- $1 \beta$; and the M1 marker gene iNOS were significantly increased in M1 macrophages from the SIRT1 KO mice compared with those from the WT mouse macrophages. In contrast, SRT1720 treatment decreased the expression of CCR2 and CXCL10, TNF- $\alpha$, IL-6, iNOS, and CD86 mRNAs in M1 BMDMs from WT mice (Fig. 10C). Together, these results indicated that SIRT1 regulated macrophage migration via CCR2 and CXCL10, M1 activation, and secretion of inflammatory cytokines in vitro.

\section{Discussion}

The purpose of this study was to investigate the beneficial effects of targeting SIRT1 in injured spinal cords, with particular emphasis on targeting the immunomodulatory function of SIRT1. Moreover, we attempted to elucidate the mechanism by which SRT1720, an SIRT1 agonist, protects mice against SCI.

In this study, SIRT1 induced significant changes in several measures of recovery in mice subjected to moderate SCI. We established Mx1-Cre-mediated SIRT1 KO mice and administered a potent SIRT1 activator, SRT1720, to the WT and SIRT1 
A

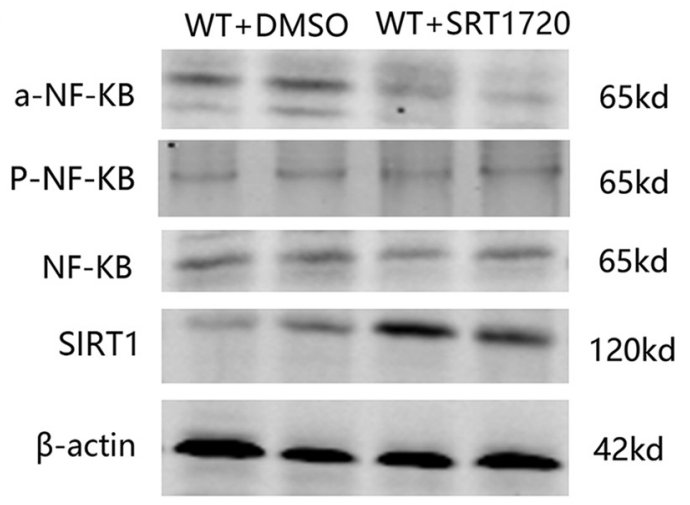

B

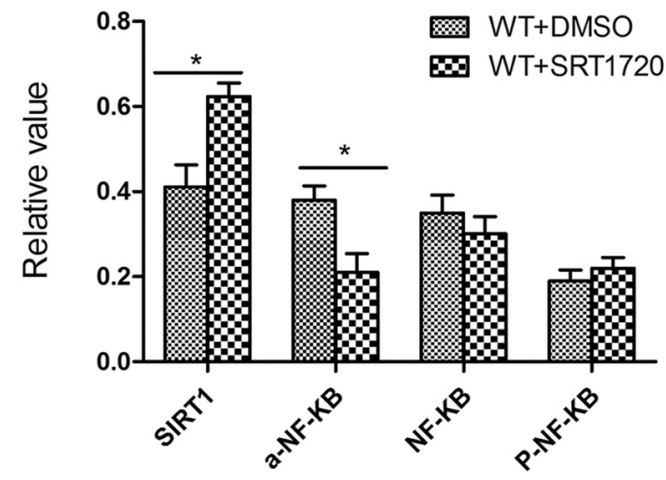

Figure 9. Analysis of the expression of SIRT1 and its downstream target via WB. $\boldsymbol{A}$, The SRT1720 - and DMSO-treated groups were examined by WB at $24 \mathrm{hpi}$. $B$, Upregulation of SIRT1 $(p=0.012)$ by SRT1720 induced a reduction in acetyl-NF- $\kappa B$ p65 $(p=0.023)$. The data are presented as the mean \pm SEM. ${ }^{*} p<0.05 ;{ }^{* *} p<0.01$ ( $n=4$ /group). Bars represent the mean \pm SEM.

KO mice to target SIRT1. The SIRT1 KO mice were suitable for investigating the effects of SIRT1 on inflammatory cells because the efficiency of Mx1-Cre-mediated gene KO differs across various tissues and cells. As shown in Figure 1, the majority of SIRT1 protein expression was knocked out in inflammatory cells, but very little was knocked out in the spinal cord of SIRT1 KO mice. We revealed that the decreased SIRT1 expression in the epicenter of the injured spinal cord began 4 hpi and persisted for $3 \mathrm{~d}$ after SCI. SRT1720 was thought to be a potent and efficient selective SIRT1 activator identified in a small molecule screen for SIRT1 agonists (Milne et al., 2007; Chauhan et al., 2011). Our study showed that following SRT1720 administration to the WT mice, better recovery at the functional and cellular levels was observed for 4 weeks after SCI; this recovery included increased BMS scores, reduced levels of inflammatory cytokines, and reduced inflammatory cell presence for $14 \mathrm{~d}$ after injury. In contrast, administration of SRT1720 to the SIRT1 KO mice had no effect on functional recovery and did not attenuate inflammation. Interestingly, the SIRT1 KO mice exhibited severe inhibition of locomotor recovery and a detrimental inflammatory response compared with those of the WT mice. It is known that SRT1720 interacts directly with SIRT1 and triggers SIRT1catalyzed deacetylation via an allosteric mechanism (Dai et al., 2010; Kulkarni et al., 2016). Activation of SIRT1 expression by SIRT1 activating compounds is dependent on structural features of the substrate (Miller, 1999; Dai et al., 2010; Pacholec et al., 2010; Kulkarni et al., 2016). Thus, we concluded that SRT1720, an SIRT1 agonist, improved locomotor recovery primarily due to the effects of SIRT1 on posttraumatic inflammation after SCI.
Inflammatory cytokines are important components of posttraumatic inflammation and play critical roles in functional recovery (Popovich et al., 1997; Guízar-Sahagún et al., 2004; Allison and Ditor, 2015). Proinflammatory cytokines, such as TNF- $\alpha$, IL- 6 , and IL- $1 \beta$, have been reported to induce necrotic and apoptotic cell death and decrease locomotor function after SCI, while suppression of these cytokines promotes neuronal survival and attenuates the severity of SCI (Sharma et al., 2003; Ledesma et al., 2004; Allan et al., 2005; Nakamura et al., 2005; Simi et al., 2007; Sheikpranbabu et al., 2009; Tolosa et al., 2011; Burke et al., 2014; Lin et al., 2016; Amini Pishva et al., 2016). Our results showed that following SRT1720 administration to WT mice, there was a significant reduction in the levels of proinflammatory cytokines, including TNF- $\alpha$, IL- 6 and IL- $1 \beta$, in the early postinjury stages and that the SIRT1 KO mice exhibited increased levels of these inflammatory cytokines compared with those of WT mice (Fig. 5). In contrast, there were no differences in the production of proinflammatory cytokines between the SRT1720SIRT1 KO mice and the DMSO-SIRT1 KO mice. Together, these results suggest that SIRT1 affects the recovery of motor function after SCI partially by controlling inflammatory cytokine production. The SIRT1 protein is directly associated with the RelA/p65 subunit of NF- $\kappa \mathrm{B}$ and deacetylates the Lys310 residue of RelA/ $\mathrm{p} 65$, a site that is critical for NF- $\kappa \mathrm{B}$ transcriptional activity (Chen et al., 2002). Previous studies have also demonstrated that SIRT1 regulates inflammatory cytokine production by deacetylating the Lys310 residue of RelA/p65 (Zhu et al., 2011; Moon et al., 2013). Thus, we analyzed NF- $\kappa$ B and acetylated-NF- $\kappa$ B via WB, and our results showed that SRT1720 administration inhibited the acetylation of Lys310 in RelA/p65, a site that is critical for NF- $\kappa \mathrm{B}$ activity, in vivo, whereas it did not influence total NF- $\kappa \mathrm{B}$ expression (Fig. 9). Therefore, we conclude that SIRT1 activation attenuated inflammation by suppressing NF- $\kappa \mathrm{B}$ activation, the transcription of which regulates the expressions of IL- $1 \beta$, IL- 6 , and TNF- $\alpha$.

Following this alteration in inflammatory cytokines, we identified a significant reduction in the number of macrophages $/ \mathrm{mi}$ croglia and perivascular macrophages after administration of SRT1720 to the WT mice. Interestingly, we found that the SIRT1 KO mice exhibited increases in perivascular macrophages compared with those of the WT mice at $14 \mathrm{~d}$ after injury. Previous studies have shown that macrophages/microglia play pivotal roles in traumatic SCI and in the progression of certain CNS diseases, including multiple sclerosis, Alzheimer's disease, and Parkinson's disease (Akiyama, 1994; Kurkowska-Jastrzebska et al., 1999; Howell et al., 2010). Popovich reported that decreased macrophage accumulation at the SCI site is neuroprotective and facilitates locomotor recovery (Popovich et al., 1999). Our data revealed that SIRT1 could regulate macrophage infiltration and macrophage accumulation in vivo, which may explain the observed locomotor recovery after injury.

To further explore the mechanism of macrophage infiltration, we analyzed the expression of chemokine, chemokine receptor, and inflammatory cytokine genes in BMDMs via RT-PCR to obtain a better understanding of the role of SIRT1 in macrophage migration. We found that the levels of CCR2, CXCL10, TNF- $\alpha$, IL-6, and IL- $1 \beta$ mRNAs increased in the SIRT1 KO macrophages compared with those of the WT macrophages. However, SRT1720 administration to WT BMDMs decreased the mRNA levels of CCR2, CXCL10, TNF- $\alpha$, and IL-6. CCR2 is an important chemokine receptor in CNS injury. Hsieh et al. (2014), Ka et al. (2015), and Morganti et al. (2015) reported that increased CCR2 expression may directly trigger the recruitment of macrophages 
A

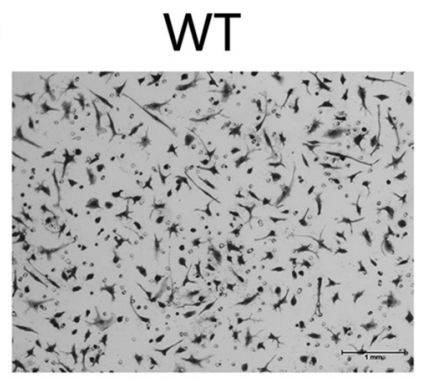

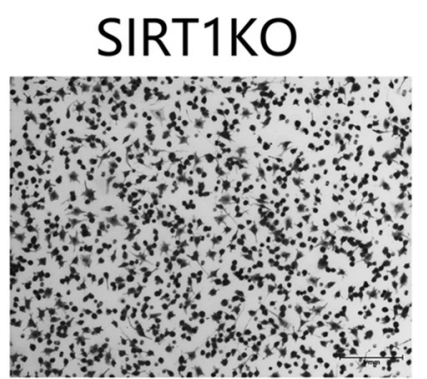
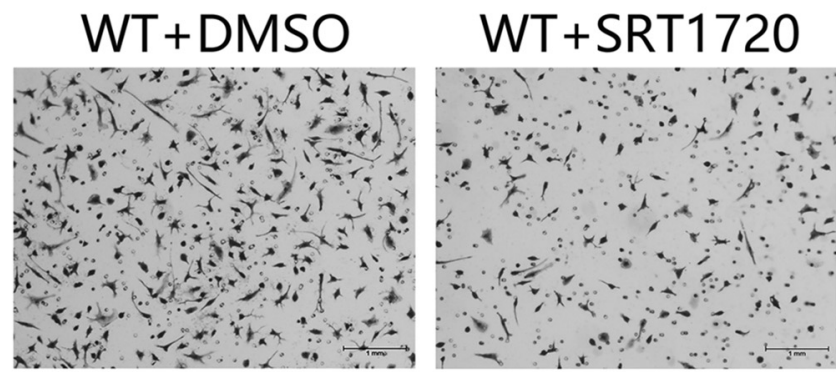

B
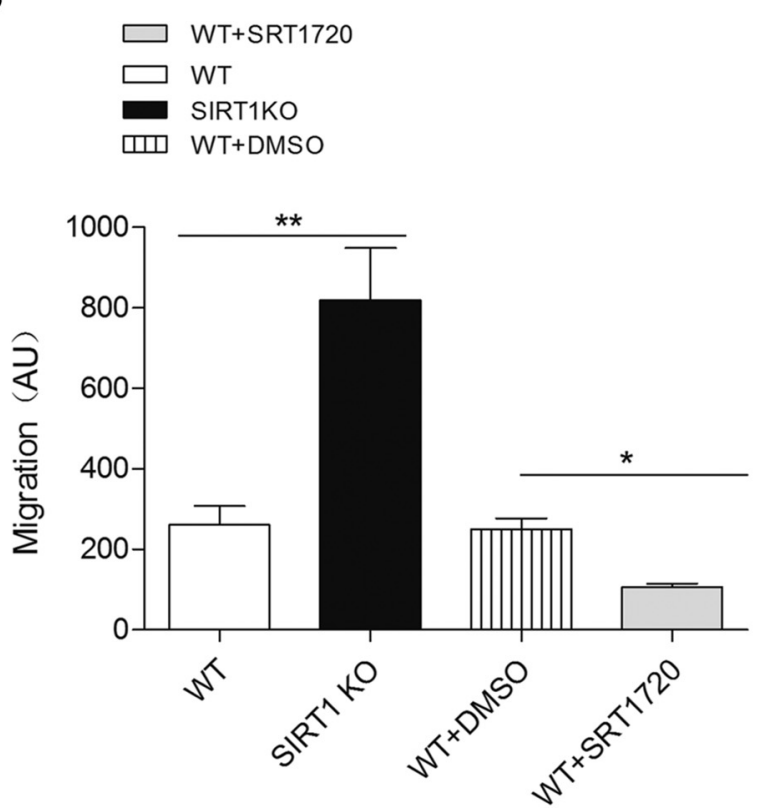

C
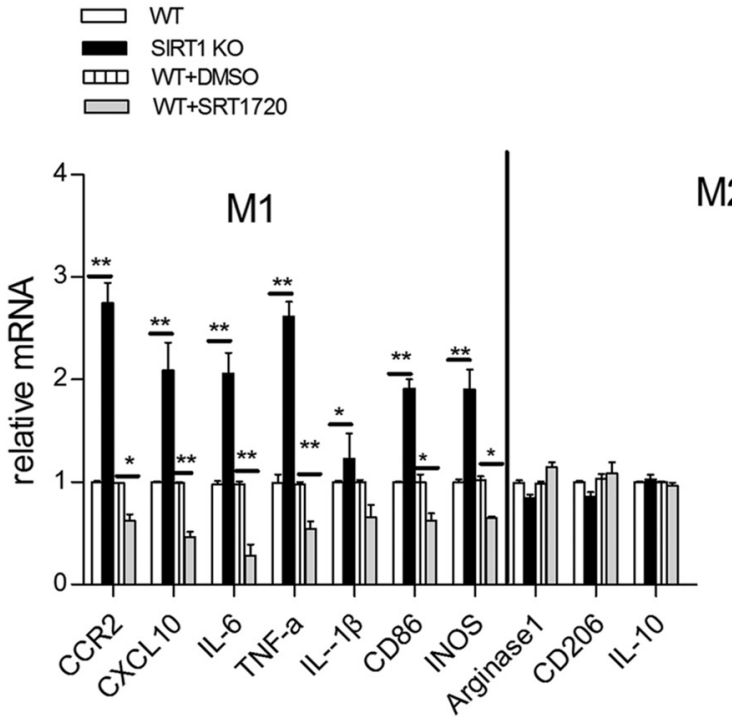

Figure 10. Regulation of macrophage genes by SIRT1. $\boldsymbol{A}, \boldsymbol{B}, \mathrm{BMDMs}$ from WT or SIRT1 K0 mice were allowed to migrate through porous membranes toward $600 \mathrm{\mu l}$ of serum-free DMEM supplemented with CCL2 $(1 \mathrm{ng} / \mathrm{ml})$ for $24 \mathrm{~h}$. BMDMs from the WT mice were treated with $15 \mathrm{~nm}$ SRT1720 for $24 \mathrm{~h}$, and migration toward the medium described above was determined. The number

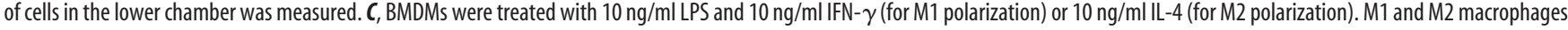
were separately treated with $15 \mathrm{~nm}$ SRT1720 for $24 \mathrm{~h}$. The expression levels of M1 markers, M2 markers, chemotaxis receptors, and chemokine and inflammatory genes were analyzed using RT-PCR. Scale bar, $1 \mathrm{~mm} .{ }^{*} p<0.05 ;{ }^{* *} p<0.01$. The values are presented as the mean $\pm \mathrm{SEM}$ ( $n=3 /$ group).

to the CNS and that decreased expression impaired macrophage infiltration into the CNS. Our results support and complement a previous study in mice showing that SIRT1 regulates macrophage infiltration via CCR2. Moreover, several studies have reported that CXCL10, a member of the $\alpha(\mathrm{C}-\mathrm{X}-\mathrm{C})$ subfamily and an established $\mathrm{T}$ cell and macrophage chemoattractant, contributes to macrophage migration (Luster and Leder, 1993; Vogel et al., 2014). Thus, we concluded that SIRT1 plays an important role in macrophage infiltration via CCR2 and CXCL10 after SCI. Furthermore, the downregulation of proinflammatory cytokines that typically function as potent attractants for monocytes/macrophages may reduce macrophage infiltration following SCI.

We also assessed macrophage polarization in the spinal cord using RT-PCR, WB, and double-labeling immunofluorescence to further investigate the phenotypes of affected macrophages. As indicated in previous publications, decreasing M1 macrophage activation following SCI may be a promising therapeutic strategy. In transgenic models of SCI, decreasing the number of M1 macrophages led to improved recovery, whereas decreasing the number of M2 macrophages or increasing the number of M1 macrophages impaired SCI recovery (Popovich et al., 1999; Schwartz and Yoles, 2006; Donnelly et al., 2011; Shechter et al., 2013; Bartus et al., 2014; Fenn et al., 2014; Kroner et al., 2014). In the current study, a decrease in the levels of M1 polarization markers was observed in the SRT1720-treated WT mice at $14 \mathrm{~d}$ after injury, and the SIRT1 agonist influenced the expression of the M1 markers CD86 and iNOS. In contrast, the SIRT1 KO mice exhibited significant increases in CD86 and iNOS levels compared with those of the WT mice. In vitro experiments showed that macrophages from KO mice were more susceptible to M1 activation and that SRT1720 treatment decreased the mRNA expression of iNOS and CD86 in M1 BMDMs from WT mice. Therefore, we conclude that SIRT1 regulates M1 polarization, which is consistent with a previous study (Ka et al., 2015). However, the mechanisms by which M1 macrophage differentiation is associated with SIRT1 remain to be elucidated.

In conclusion, our results reveal that a potent SIRT1-specific agonist, SRT1720, may have dramatic effects on inflammation, microglial/macrophage polarization, and the accumulation of macrophages following SCI. Moreover, these effects significantly improve functional recovery after injury. This study is the first to reveal that SIRT1 is a novel protective factor that enhances recovery after SCI, and therefore, the SIRT1 agonist SRT1720 may have great potential for use as a novel therapeutic agent following SCI. 


\section{References}

Akiyama H (1994) [Alzheimer's disease and the immune system response]. Nihon Rinsho 52:2990-2994. Medline

Allan SM, Tyrrell PJ, Rothwell NJ (2005) Interleukin-1 and neuronal injury. Nat Rev Immunol 5:629-640. CrossRef Medline

Allison DJ, Ditor DS (2015) Immune dysfunction and chronic inflammation following spinal cord injury. Spinal Cord 53:14-18. CrossRef Medline

Alonzi T, Maritano D, Gorgoni B, Rizzuto G, Libert C, Poli V (2001) Essential role of STAT3 in the control of the acute-phase response as revealed by inducible gene inactivation [correction of activation] in the liver. Mol Cell Biol 21:1621-1632. CrossRef Medline

Ambrozaitis K, Kontautas E, Spakauskas B, Vaitkaitis D (2005) Pathophysiology of acute spinal cord injury. Medicina (Kaunas) 42:255-261. Medline

Amin B, Abnous K, Motamedshariaty V, Hosseinzadeh H (2014) Attenuation of oxidative stress, inflammation and apoptosis by ethanolic and aqueous extracts of Crocus sativus L. stigma after chronic constriction injury of rats. An Acad Bras Cienc 86:1821-1832. CrossRef Medline

Amini Pishva A, Akbari M, Farahabadi A, Arabkheradmand A, Beyer C, Dashti N, Moradi F, Hassanzadeh G (2016) Effect of estrogen therapy on TNF- $\alpha$ and iNOS gene expression in spinal cord injury model. Acta Med Iran 54:296-301. Medline

Bartus K, James ND, Didangelos A, Bosch KD, Verhaagen J, Yáñez-Muñoz RJ, Rogers JH, Schneider BL, Muir EM, Bradbury EJ (2014) Large-scale chondroitin sulfate proteoglycan digestion with chondroitinase gene therapy leads to reduced pathology and modulates macrophage phenotype following spinal cord contusion injury. J Neurosci 34:4822-4836. CrossRef Medline

Basso DM, Fisher LC, Anderson AJ, Jakeman LB, McTigue DM, Popovich PG (2006) Basso mouse scale for locomotion detects differences in recovery after spinal cord injury in five common mouse strains. J Neurotrauma 23:635-659. CrossRef Medline

Beattie MS (2004) Inflammation and apoptosis: linked therapeutic targets in spinal cord injury. Trends Mol Med 10:580-583. CrossRef Medline

Bethea JR (2000) Spinal cord injury-induced inflammation: a dual-edged sword. Prog Brain Res 128:33-42. CrossRef Medline

Bethea JR, Castro M, Keane RW, Lee TT, Dietrich WD, Yezierski RP (1998) Traumatic spinal cord injury induces nuclear factor- $\kappa \mathrm{B}$ activation. J Neurosci 18:3251-3260. Medline

Borda JT, Alvarez X, Mohan M, Ratterree MS, Phillippi-Falkenstein K, Lackner AA, Bunnell BA (2008) Clinical and immunopathologic alterations in rhesus macaques affected with globoid cell leukodystrophy. Am J Pathol 172:98-111. CrossRef Medline

Bordone L, Guarente L (2005) Calorie restriction, SIRT1 and metabolism: understanding longevity. Nat Rev Mol Cell Biol 6:298-305. CrossRef Medline

Burgess AW, MetcalfD, Kozka IJ, Simpson RJ, Vairo G, Hamilton JA, Nice EC (1985) Purification of two forms of colony-stimulating factor from mouse L-cell-conditioned medium. J Biol Chem 260:16004-16011. Medline

Burke SJ, Lu D, Sparer TE, Karlstad MD, Collier JJ (2014) Transcription of the gene encoding TNF- $\alpha$ is increased by IL- $1 \beta$ in rat and human islets and $\beta$-cell lines. Mol Immunol 62:54-62. CrossRef Medline

Busch F, Mobasheri A, Shayan P, Stahlmann R, Shakibaei M (2012) Sirt-1 is required for the inhibition of apoptosis and inflammatory responses in human tenocytes. J Biol Chem 287:25770-25781. CrossRef Medline

Busch SA, Horn KP, Silver DJ, Silver J (2009) Overcoming macrophagemediated axonal dieback following CNS injury. J Neurosci 29:9967-9976. CrossRef Medline

Cassetta L, Cassol E, Poli G (2011) Macrophage polarization in health and disease. ScientificWorldJournal 11:2391-2402. CrossRef Medline

Chauhan D, Bandi M, Singh AV, Ray A, Raje N, Richardson P, Anderson KC (2011) Preclinical evaluation of a novel SIRT1 modulator SRT1720 in multiple myeloma cells. Br J Haematol 155:588-598. CrossRef Medline

Chen LF, Mu Y, Greene WC (2002) Acetylation of RelA at discrete sites regulates distinct nuclear functions of NF-kappaB. EMBO J 21:65396548. CrossRef Medline

Cheng H, Cao Y, Olson L (1996) Spinal cord repair in adult paraplegic rats: partial restoration of hind limb function. Science 273:510-513. CrossRef Medline

Conti A, Cardali S, Genovese T, Di Paola R, La Rosa G (2003) Role of in- flammation in the secondary injury following experimental spinal cord trauma. J Neurosurg Sci 47:89-94. Medline

Courtine G, van den Brand R, Musienko P (2011) Spinal cord injury: time to move. Lancet 377:1896-1898. CrossRef Medline

Dai H, Kustigian L, Carney D, Case A, Considine T, Hubbard BP, Perni RB, Riera TV, Szczepankiewicz B, Vlasuk GP, Stein RL (2010) SIRT1 activation by small molecules: kinetic and biophysical evidence for direct interaction of enzyme and activator. J Biol Chem 285:32695-32703. CrossRef Medline

David S, Kroner A (2011) Repertoire of microglial and macrophage responses after spinal cord injury. Nat Rev Neurosci 12:388-399. CrossRef Medline

David S, López-Vales R, Wee Yong V (2012a) Harmful and beneficial effects of inflammation after spinal cord injury: potential therapeutic implications. Handb Clin Neurol 109:485-502. CrossRef Medline

David S, Zarruk JG, Ghasemlou N (2012b) Inflammatory pathways in spinal cord injury. Int Rev Neurobiol 106:127-152. CrossRef Medline

Donnelly DJ, Longbrake EE, Shawler TM, Kigerl KA, Lai W, Tovar CA, Ransohoff RM, Popovich PG (2011) Deficient CX3CR1 signaling promotes recovery after mouse spinal cord injury by limiting the recruitment and activation of Ly6Clo/iNOS+ macrophages. J Neurosci 31:9910-9922. CrossRef Medline

Dumont RJ, Verma S, Okonkwo DO, Hurlbert RJ, Boulos PT, Ellegala DB, Dumont AS (2001) Acute spinal cord injury, part II: contemporary pharmacotherapy. Clin Neuropharmacol 24:265-279. CrossRef Medline

Fehlings MG, Baptiste DC (2005) Current status of clinical trials for acute spinal cord injury. Injury 36 [Suppl 2]:B113-B122.

Fenn AM, Hall JC, Gensel JC, Popovich PG, Godbout JP (2014) IL-4 signaling drives a unique arginase $+/ \mathrm{IL}-1 \beta+$ microglia phenotype and recruits macrophages to the inflammatory CNS: consequences of age-related deficits in IL-4R $\alpha$ after traumatic spinal cord injury. J Neurosci 34:89048917. CrossRef Medline

Fleming JC, Norenberg MD, Ramsay DA, Dekaban GA, Marcillo AE, Saenz AD, Pasquale-Styles M, Dietrich WD, Weaver LC (2006) The cellular inflammatory response in human spinal cords after injury. Brain 129: 3249-3269. CrossRef Medline

Gensel JC, Nakamura S, Guan Z, van Rooijen N, Ankeny DP, Popovich PG (2009) Macrophages promote axon regeneration with concurrent neurotoxicity. J Neurosci 29:3956-3968. CrossRef Medline

Gordon S (2003) Alternative activation of macrophages. Nat Rev Immunol 3:23-35. CrossRef Medline

Guízar-Sahagún G, Velasco-Hernández L, Martínez-Cruz A, CastañedaHernández G, Bravo G, Rojas G, Hong E (2004) Systemic microcirculation after complete high and low thoracic spinal cord section in rats. J Neurotrauma 21:1614-1623. CrossRef Medline

Hall ED, Springer JE (2004) Neuroprotection and acute spinal cord injury: a reappraisal. Neurorx 1:80-100. CrossRef Medline

Hawkes CA, McLaurin J (2009) Selective targeting of perivascular macrophages for clearance of beta-amyloid in cerebral amyloid angiopathy. Proc Natl Acad Sci U S A 106:1261-1266. CrossRef Medline

He W, Wang Y, Zhang MZ, You L, Davis LS, Fan H, Yang HC, Fogo AB, Zent R, Harris RC, Breyer MD, Hao CM (2010) Sirtl activation protects the mouse renal medulla from oxidative injury. J Clin Invest 120:1056-1068. CrossRef Medline

Hirz T, Dumontet C (2016) Neutrophil isolation and analysis to determine their role in lymphoma cell sensitivity to therapeutic agents. J Vis Exp e53846.

Howell OW, Rundle JL, Garg A, Komada M, Brophy PJ, Reynolds R (2010) Activated microglia mediate axoglial disruption that contributes to axonal injury in multiple sclerosis. J Neuropathol Exp Neurol 69:10171033. CrossRef Medline

Hsieh CL, Niemi EC, Wang SH, Lee CC, Bingham D, Zhang J, Cozen ML, Charo I, Huang EJ, Liu J, Nakamura MC (2014) CCR2 deficiency impairs macrophage infiltration and improves cognitive function after traumatic brain injury. J Neurotrauma 31:1677-1688. CrossRef Medline

Ka SO, Song MY, Bae EJ, Park BH (2015) Myeloid SIRT1 regulates macrophage infiltration and insulin sensitivity in mice fed a high-fat diet. J Endocrinol 224:109-118. CrossRef Medline

Kauppinen A, Suuronen T, Ojala J, Kaarniranta K, Salminen A (2013) Antagonistic crosstalk between NF- $\kappa \mathrm{B}$ and SIRT1 in the regulation of inflammation and metabolic disorders. Cell Signal 25:1939-1948. CrossRef Medline 
Kigerl KA, Gensel JC, Ankeny DP, Alexander JK, Donnelly DJ, Popovich PG (2009) Identification of two distinct macrophage subsets with divergent effects causing either neurotoxicity or regeneration in the injured mouse spinal cord. J Neurosci 29:13435-13444. CrossRef Medline

Kroner A, Greenhalgh AD, Zarruk JG, Passos Dos Santos R, Gaestel M, David S (2014) TNF and increased intracellular iron alter macrophage polarization to a detrimental M1 phenotype in the injured spinal cord. Neuron 83:1098-1116. CrossRef Medline

Kühn R, Schwenk F, Aguet M, Rajewsky K (1995) Inducible gene targeting in mice. Science 269:1427-1429. CrossRef Medline

Kulkarni SR, Soroka CJ, Hagey LR, Boyer JL (2016) Sirtuin 1 activation alleviates cholestatic liver injury in a cholic acid-fed mouse model of cholestasis. Hepatology 64:2151-2164. CrossRef Medline

Kuo HS, Tsai MJ, Huang MC, Huang WC, Lee MJ, Kuo WC, You LH, Szeto KC, Tsai IL, Chang WC, Chiu CW, Ma H, Chak KF, Cheng H (2007) The combination of peripheral nerve grafts and acidic fibroblast growth factor enhances arginase I and polyamine spermine expression in transected rat spinal cords. Biochem Biophys Res Commun 357:1-7. CrossRef Medline

Kuo HS, Tsai MJ, Huang MC, Chiu CW, Tsai CY, Lee MJ, Huang WC, Lin YL, Kuo WC, Cheng H (2011) Acid fibroblast growth factor and peripheral nerve grafts regulate Th2 cytokine expression, macrophage activation, polyamine synthesis, and neurotrophin expression in transected rat spinal cords. J Neurosci 31:4137-4147. CrossRef Medline

Kurkowska-Jastrzebska I, Wrońska A, Kohutnicka M, Członkowski A, Członkowska A (1999) MHC class II positive microglia and lymphocytic infiltration are present in the substantia nigra and striatum in mouse model of Parkinson's disease. Acta Neurobiol Exp 59:1-8. Medline

Kwon BK, Tetzlaff W, Grauer JN, Beiner J, Vaccaro AR (2004) Pathophysiology and pharmacologic treatment of acute spinal cord injury. Spine J 4:451-464. CrossRef Medline

Lam KP, Rajewsky K (1998) Rapid elimination of mature autoreactive B cells demonstrated by Cre-induced change in B cell antigen receptor specificity in vivo. Proc Natl Acad Sci U S A 95:13171-13175. CrossRef Medline

Lam KP, Kühn R, Rajewsky K (1997) In vivo ablation of surface immunoglobulin on mature $\mathrm{B}$ cells by inducible gene targeting results in rapid cell death. Cell 90:1073-1083. CrossRef Medline

Layoun A, Samba M, Santos MM (2015) Isolation of murine peritoneal macrophages to carry out gene expression analysis upon toll-like receptors stimulation. J Vis Exp e52749.

Ledesma E, Martínez I, Córdova Y, Rodríguez-Sosa M, Monroy A, Mora L, Soto I, Ramos G, Weiss B, Santiago Osorio E (2004) Interleukin-1 beta (IL-1beta) induces tumor necrosis factor alpha (TNF-alpha) expression on mouse myeloid multipotent cell line 32D cl3 and inhibits their proliferation. Cytokine 26:66-72. CrossRef Medline

Lim JH, Kim EN, Kim MY, Chung S, Shin SJ, Kim HW, Yang CW, Kim YS, Chang YS, Park CW, Choi BS (2012) Age-associated molecular changes in the kidney in aged mice. Oxid Med Cell Longev 2012:171383. Medline

Lin WP, Lin JH, Cai B, Shi JX, Li WJ, Choudhury GR, Wu SQ, Wu JZ, Wu HP, Ke QF (2016) Effect of adenovirus-mediated RNA interference of IL-1 $\beta$ expression on spinal cord injury in rats. Spinal Cord 54:778-784. CrossRef Medline

Luster AD, Leder P (1993) IP-10, a -C-X-C- chemokine, elicits a potent thymus-dependent antitumor response in vivo. J Exp Med 178:10571065. CrossRef Medline

Maier IC, Schwab ME (2006) Sprouting, regeneration and circuit formation in the injured spinal cord: factors and activity. Philos Trans R Soc Lond B Biol Sci 361:1611-1634. CrossRef Medline

Mantovani A, Sica A, Sozzani S, Allavena P, Vecchi A, Locati M (2004) The chemokine system in diverse forms of macrophage activation and polarization. Trends Immunol 25:677-686. CrossRef Medline

Miller LK (1999) An exegesis of IAPs: salvation and surprises from BIR motifs. Trends Cell Biol 9:323-328. CrossRef Medline

Milne JC, Lambert PD, Schenk S, Carney DP, Smith JJ, Gagne DJ, Jin L, Boss O, Perni RB, Vu CB, Bemis JE, Xie R, Disch JS, Ng PY, Nunes JJ, Lynch AV, Yang H, Galonek H, Israelian K, Choy W, et al. (2007) Small molecule activators of SIRT1 as therapeutics for the treatment of type 2 diabetes. Nature 450:712-716. CrossRef Medline

Moon MH, Jeong JK, Lee YJ, Seol JW, Jackson CJ, Park SY (2013) SIRT1, a class III histone deacetylase, regulates TNF- $\alpha$-induced inflammation in human chondrocytes. Osteoarthritis Cartilage 21:470-480. CrossRef Medline

Morganti JM, Jopson TD, Liu S, Riparip LK, Guandique CK, Gupta N, Ferguson AR, Rosi S (2015) CCR2 antagonism alters brain macrophage polarization and ameliorates cognitive dysfunction induced by traumatic brain injury. J Neurosci 35:748-760. CrossRef Medline

Mullane KM, Kraemer R, Smith B (1985) Myeloperoxidase activity as a quantitative assessment of neutrophil infiltration into ischemic myocardium. J Pharmacol Methods 14:157-167. CrossRef Medline

Nakamura M, Okada S, Toyama Y, Okano H (2005) Role of IL-6 in spinal cord injury in a mouse model. Clin Rev Allergy Immunol 28:197-204. CrossRef Medline

Pacholec M, Bleasdale JE, Chrunyk B, Cunningham D, Flynn D, Garofalo RS, Griffith D, Griffor M, Loulakis P, Pabst B, Qiu X, Stockman B, Thanabal V, Varghese A, Ward J, Withka J, Ahn K (2010) SRT1720, SRT2183, SRT1460, and resveratrol are not direct activators of SIRT1. J Biol Chem 285:8340-8351. CrossRef Medline

Pomeshchik Y, Kidin I, Savchenko E, Rolova T, Yamamoto M, Levonen AL, Ylä-Herttuala S, Malm T, Kanninen K, Koistinaho J (2014) Does Nrf2 gene transfer facilitate recovery after contusion spinal cord injury? Antioxid Redox Signal 20:1313-1323. CrossRef Medline

Popovich PG, Wei P, Stokes BT (1997) Cellular inflammatory response after spinal cord injury in Sprague-Dawley and Lewis rats. J Comp Neurol 377:443-464. CrossRef Medline

Popovich PG, Guan Z, Wei P, Huitinga I, van Rooijen N, Stokes BT (1999) Depletion of hematogenous macrophages promotes partial hindlimb recovery and neuroanatomical repair after experimental spinal cord injury. Exp Neurol 158:351-365. CrossRef Medline

Profyris C, Cheema SS, Zang D, Azari MF, Boyle K, Petratos S (2004) Degenerative and regenerative mechanisms governing spinal cord injury. Neurobiol Dis 15:415-436. CrossRef Medline

Radtke F, Wilson A, Stark G, Bauer M, van Meerwijk J, MacDonald HR, Aguet M (1999) Deficient T cell fate specification in mice with an induced inactivation of Notch1. Immunity 10:547-558. CrossRef Medline

Rohlmann A, Gotthardt M, Hammer RE, Herz J (1998) Inducible inactivation of hepatic LRP gene by cre-mediated recombination confirms role of LRP in clearance of chylomicron remnants. J Clin Invest 101:689-695. CrossRef Medline

Rowland JW, Hawryluk GW, Kwon B, Fehlings MG (2008) Current status of acute spinal cord injury pathophysiology and emerging therapies: promise on the horizon. Neurosurg Focus 25:E2. Medline

Schwartz M, Yoles E (2006) Immune-based therapy for spinal cord repair: autologous macrophages and beyond. J Neurotrauma 23:360-370. CrossRef Medline

Sharma HS, Winkler T, Stålberg E, Gordh T, Alm P, Westman J (2003) Topical application of TNF-alpha antiserum attenuates spinal cord trauma induced edema formation, microvascular permeability disturbances and cell injury in the rat. Acta Neurochir Suppl 86:407-413. Medline

Shechter R, Miller O, Yovel G, Rosenzweig N, London A, Ruckh J, Kim KW, Klein E, Kalchenko V, Bendel P, Lira SA, Jung S, Schwartz M (2013) Recruitment of beneficial M2 macrophages to injured spinal cord is orchestrated by remote brain choroid plexus. Immunity 38:555-569. CrossRef Medline

Sheikpranbabu S, Kalishwaralal K, Venkataraman D, Eom SH, Park J, Gurunathan S (2009) Silver nanoparticles inhibit VEGF-and IL-1 $\beta$ induced vascular permeability via Src dependent pathway in porcine retinal endothelial cells. J Nanobiotechnol 7:8. CrossRef

Shinozaki S, Chang K, Sakai M, Shimizu N, Yamada M, Tanaka T, Nakazawa H, Ichinose F, Yamada Y, Ishigami A, Ito H, Ouchi Y, Starr ME, Saito H, Shimokado K, Stamler JS, Kaneki M (2014) Inflammatory stimuli induce inhibitory S-nitrosylation of the deacetylase SIRT1 to increase acetylation and activation of p53 and p65. Sci Signal 7:ra106. CrossRef Medline

Siegel RW, Velappan N, Pavlik P, Chasteen L, Bradbury A (2004) Recombinatorial cloning using heterologous lox sites. Genome Res 14:1119-1129. CrossRef Medline

Simi A, Tsakiri N, Wang P, Rothwell NJ (2007) Interleukin-1 and inflammatory neurodegeneration. Biochem Soc Trans 35:1122-1126. CrossRef Medline

Tassone G, Fidler SJ (2012) Separation and cryopreservation of lympho- 
cytes from spleen and lymph node. Methods Mol Biol 882:351-357. CrossRef Medline

Tavernier SJ, Osorio F, Janssens S, Lambrecht BN (2015) Isolation of splenic dendritic cells using fluorescence-activated cell sorting. Bio Protoc 5:e1415. Medline

Tolosa L, Caraballo-Miralles V, Olmos G, Lladó J (2011) TNF- $\alpha$ potentiates glutamate-induced spinal cord motoneuron death via NF- $\kappa$ B. Mol Cell Neurosci 46:176-186. CrossRef Medline

Vogel DY, Heijnen PD, Breur M, de Vries HE, Tool AT, Amor S, Dijkstra CD (2014) Macrophages migrate in an activation-dependent manner to chemokines involved in neuroinflammation. J Neuroinflammation 11: 23. CrossRef Medline

Wang X, Cao K, Sun X, Chen Y, Duan Z, Sun L, Guo L, Bai P, Sun D, Fan J, He X, Young W, Ren Y (2015) Macrophages in spinal cord injury: pheno- typic and functional change from exposure to myelin debris. Glia 63:635651. CrossRef Medline

Xie J, Zhang X, Zhang L (2013) Negative regulation of inflammation by SIRT1. Pharmacol Res 67:60-67. CrossRef Medline

Yeung F, Hoberg JE, Ramsey CS, Keller MD, Jones DR, Frye RA, Mayo MW (2004) Modulation of NF- $\kappa$ B-dependent transcription and cell survival by the SIRT1 deacetylase. EMBO J 23:2369-2380. CrossRef Medline

Zhang B, Gensel JC (2014) Is neuroinflammation in the injured spinal cord different than in the brain? Examining intrinsic differences between the brain and spinal cord. Exp Neurol 258:112-120. CrossRef Medline

Zhu X, Liu Q, Wang M, Liang M, Yang X, Xu X, Zou H, Qiu J (2011) Activation of Sirt1 by resveratrol inhibits TNF- $\alpha$ induced inflammation in fibroblasts. PLoS One 6:e27081. CrossRef Medline 